\title{
POČÁTKY NEUROLOGIE NA PRAŽSKÝCH LÉKAŘSKÝCH FAKULTÁCH A ZALOŽENÍ NEUROLOGICKÝCH KLINIK
}

\author{
LUDMILA HLAVÁČKOVÁ
}

\section{THE BEGINNINGS OF NEUROLOGY AT FACULTIES OF MEDICINE IN PRAGUE AND FOUNDATION OF NEUROLOGY CLINICS}

The author follows the development of neurology at medical schools in Prague since the earliest times until the 1930s. Based on lists of lectures, she traces how particular subjects were taught within mandatory courses. In the 1840 s, there appeared the first facultative specialised lectures, some of which later became mandatory as part of requirements for earning a degree. Special attention is paid to Ladislav Haškovec (1866-1944), professor of neurology, and his efforts to acquire hospital beds reserved for patients with neurological diagnoses. The first place where he succeeded was in the Hospital of Merciful Brethren Charity at Na Františku after 1905. A separate institute for nervous diseases was established only after 1918 in the Na Karlově infirmary. On 12 January 1926 , this institution was transformed into a Clinic for Nervous Diseases and Professor Haškovec stood at its helm until his retirement in 1936. At the German Faculty of Medicine, neurology developed in a closer connection with psychiatry.

Keywords: faculty of medicine in Prague - neurology - Professor Ladislav Haškovec - Hospital of Merciful Brethren at $\mathrm{Na}$ Františku in Prague - Na Karlově infirmary

DOI: $10.14712 / 23365730.2020 .1$

Známý pražský lékař a obrozenský pracovník J. V. Podlipský (1816-1867), manžel Sofie Podlipské a mj. pilný autor hesel v Riegrově naučném slovníku, v něm definoval neurologii takto: „Neurologie, nauka o nervech, jest část anatomie jednající o nervech.“ Pak následuje stručná historie tohoto oboru počínaje Aristotelem a konče jeho současníky. ${ }^{1}$

Čtenář této definice může nabýt dojmu, že v 60. letech 19. století byla neurologie již uznávaným, byt' ještě ne samostatným medicínským oborem, který byl chápán jako součást oborů teoretických. U nás i ve světě však uběhla ještě řada desetiletí, než se neurologie stala samostatným oborem s ambulantními i klinickými pracovišti. Od přelomu 19. a 20. století se rozvíjela především klinická neurologie, nejprve v rámci interny a psychiatrie. Ve svém př́spěvku bych ráda upozornila právě na to, jak neurologie bojovala o své „místo na slunci“ na pražských lékařských fakultách, jak se dostávala k medikům nejprve v mimořádných speciálních přednáškách, stávala se nezávislou na vnitřním lékařství i psychiatrii, jak posléze získala svá první specializovaná klinická lůžka, stala se jedním z rigorózních oborů a posléze se dočkala založení neurologické kliniky.

1 František L. Rieger (ed.), Slovník naučný, V, Praha 1866, s. 801. 


\section{Od nejstarších dob do osvícenských reforem²}

Odpověd' na otázku, kdy se poprvé objevují neurologická témata v českém akademickém prostředí, se hledá velmi obtižně, protože historie jednotlivých medicínských oborů v předosvícenském období je v našich dějinách medicíny zpracována jen zcela útržkovitě. Přesto je však možno vyzdvihnout několik zajímavých informací o neurologii na středověké a raně novověké pražské lékařské fakultě.

Patrně nejstarší dílo sepsané profesorem Univerzity Karlovy, které se zabývá tématem, jež bychom mohli označit za neurologické, pochází z pera Mistra Antonína z Loun. Jeho životní data nejsou známa, ale působil v Praze na počátku 15. století, v letech 1413-1415 byl dokonce rektorem univerzity. Sepsal pojednání nazvané Zda je možno pitvou ukázat, že $v$ lidské hlavě sídlí deset smysli̊?, jehož obsah zatím nebyl podroben odborné analýze. ${ }^{3} \mathrm{Ze}$ středověkých dějin univerzity další podobné dílo známo není, ale neurologická tematika pronikala do spisů, v nichž se pojednávalo o fyziologii tzv. životního ducha (spiritus vitalis). Najdeme ji např́klad v textech Albíka z Uničova (1358?-1427) či Jindřicha z Brém $(\dagger 1392 ?)^{4}$

V 16. století lékařská fakulta přežívala pouze de iure, fakticky se zde lékařské grady neudělovaly, a tak se předmětem našeho zájmu může stát až doba barokní. Ta je však snad ještě méně prozkoumaná, než perioda středověká. Nejznámější osobností byl profesor Jan Marek Marci z Kronlandu (1595-1667), proslulý lékař, matematik a fyzik, z jehož pozůstalosti v roce 1678 vydal jeho kolega a přítel, profesor Jakub Jan Václav Dobřenský z Černého Mostu (1623-1697), knihu nazvanou Služba mysli (Liturgia mentis, Ratisbonae 1678). Jde o více jak stopadesátistránkové pojednání o epilepsii, jež se přrirozeně věnuje celé řadě otázek z oblastí na hranici mezi psychologií, psychiatrií a neurologií.

Obrázek o dalším vývoji neurologických bádání si lze udělat také na základě studia učebnice všeobecného lékařství (Universa medicina practica, Norimbergae 1724), kterou vydal profesor Jan František Löw z Erlsfeldu (1648-1725). Jedná se o obsáhlý text přesahující tisíc stran, z nichž je přibližně první desetina věnována otázkám, jež bychom dnes asi též označili za neurologické. Najdeme zde např́klad pojednání o bezvědomí, letargii, ztrnulosti, mrtvici, paralýze, paréze, křečích, závrati, třesu, nespavosti, selhávání paměti, snížené inteligenci atd.

Löwova učebnice je zajímavá také tím, že obsahuje odkazy na některé zahraniční autory, kteří se v Čechách v souvislosti s tímto tématem četli. Najdeme zde slavného německého chemika 16. století Theophrasta B. Paracelsa (1493-1541), holandského reformátora medicíny Jana Baptistu van Helmonta (1580-1644), objevitele krevního oběhu Williama Harveye (1578-1657) a také zakladatele iatromechanické teorie René Descarta (1596-1650).

K tomu je možno ještě dodat, že např́íklad Descartovy představy o lidském těle, jež mají i svou neurologickou stránku, byly v Praze prokazatelně známy již na konci 17. století, kdy

2 Za zpracování této kapitoly děkuji kolegovi Karlu Černému.

3 Ludmila HlavíČKovÁ - Petr SvoBoDnÝ, Biografický slovník pražské lékařské fakulty 1348-1939, I, A-K, Praha 1988; II, L-Ž, Praha1993 (dále citován BSPLF I, II). Není-li jiná citace, jsou údaje o jednotlivých osobách převzaty z tohoto slovníku, kde jsou u každého biogramu uvedeny prameny a literatura. Totéž platí i o slovníku: Ludmila HlavÁČKovÁ - Petr SvoBodnÝ, Biographisches Lexikon der Deutschen medizinischen Fakultät in Prag, Praha 1998.

4 Ivana Firlová - Pavla Lutovská - Alena SkiPAlová, Př́spěvek k léčení moru v pozdně středověkých Čechách (Na základě spisů Albíka z Uničova), Historická demografie 11, 1987, s. 21-50, zde s. 38. 
je najdeme nejen $v$ dalších dílech již zmiňovaného Löwa z Erlsfeldu, ale také v pracích dnes málo známého profesora Jana Antonína Cassinis de Bugella (1656-1719).

\section{Od osvícenských reforem do roku 1848}

Osvícenské reformy v oblasti školství a zdravotnictví zahájila okolo poloviny 18. století panovnice Marie Terezie (1717-1780). Pro lékařské fakulty to znamenalo především zvýšení počtu učitelů a zpřísnění dohledu nad výukou a jejími metodami. Z tohoto období zde musíme opět uvést alespoň jedno jméno. Je to Jan Kr̆titel Boháč (1724-1768), profesor př́rodovědy a botaniky, který se již svojí disertací stal průkopníkem české i světové elektrofyziologie a elektroterapie, která byla další dlouhá desetiletí hlavní léčebnou metodou používanou v neurologii. ${ }^{5}$

Ne všechny reformy syna Marie Terezie, Josefa II., se setkaly s porozuměním a oceněním jak současníků, tak historiků. Avšak jeho reformy v oblasti školství, zvláště vysokého, a zdravotnictví, jsou většinou jedinečné a jejich blahodárné výsledky jsou nadčasové. Krátce po nástupu na trůn vydal Josef II. v roce 1781 tzv. direktivní pravidla, podle nichž se ve všech velkých městech monarchie budovaly zdravotní a sociální ústavy, které měly nahradit nevyhovující zařízení tohoto typu - městská, vrchnostenská, církevní apod. Byly to všeobecné nemocnice, porodnice s nalezinci, ústavy choromyslných a chorobince, předchůdci dnešních léčeben dlouhodobě nemocných. Ústavy měly sloužit klinické výchově budoucích lékařů, ranlékařư i porodních bab, což významně přispělo ke zkvalitnění výuky všech těchto kategorií zdravotníků. Pražská všeobecná nemocnice byla otevřena na přelomu roku 1790/91 a od školního roku 1791/92 do ní byla přeložena klinická výuka z nemocnice milosrdných bratří Na Františku. Nemocnice měla tři třídy, na třetí, bezplatné, se konala klinická výuka. Od počátku byla rozlišována lůžka klinická a lůžka na oddělení. Při otevření měla nemocnice 300 lůžek, z toho klinických bylo pouhých dvakrát dvanáct. Od počátku byla v nemocnici klinika interní (obvykle nazývána „lékařskác) a klinika chirurgická. Každá měla šest lůžek pro pacientky a stejný počet pro pacienty. Ostatní lůžka v nemocnici byla „oddělenská“. Kliniku řídil vždy profesor, oddělení zpočátku i pouhý lékař či ranlékař. Mezi klinikou a oddělením musela být dobrá vazba, z oddělení se vybírali vhodní pacienti na kliniku, a proto $\mathrm{v}$ roce 1812 bylo rozhodnuto, že přednosta kliniky bude vždy zároveň primářem oddělení. ${ }^{6} \mathrm{~V}$ roce 1811 vydala dvorská kancelář zajímavý dekret, který ještě více zdůraznil význam klinické výuky ve všeobecné nemocnici. Budoucí profesoři lékařské fakulty se měli rekrutovat $\mathrm{z}$ asistentů, prosektorů, praktikantů a sekundář̀ z ústavů a klinik. Tvořili tzv. „Pflanzschule der künftigen Professoren“ (,semeniště“ či škola budoucích profesorů). Všeobecná nemocnice se opravdu stala školou budoucích učitelů fakulty a centrem vědeckého rozvoje klinických oborů. ${ }^{7}$

V roce 1786 se začala pražská lékařská fakulta řídit novým studijním řádem. Studium budoucích lékařů bylo čtyřleté, magistrů chirurgie dvouleté. Další významný přínos tohoto studijního řádu bylo zdůraznění názornosti výuky. Tak např. fyziologie - zvláště důležitá

5 Zdeněk Frankenberger, Jan Křtitel Boháč, život a dílo, Praha 1951.

6 Ludmila HlaváčKová - Petr SvobodnÝ - Jan BŘízA, Dějiny všeobecné fakultní nemocnice v Praze 1790-2010, Praha 2011, s. 29nn.

7 Tamtéž, s. 40; Ivana Čornejová (ed.), Dějiny Univerzity Karlovy, II, 1622-1802, Praha 1996, s. 170nn. 
pro získání vědomostí z neurologie - musela být demonstrována nejen na mrtvolách, ale i živých zvíráatech. Studijní řád z roku 1804 pak prodloužil studium mediků na pět let, klinická výuka byla rozložena z jednoho na dva roky. Byly také předepsány učebnice, pokud přednášející používal vlastní texty, musil je předložit ke schválení. Třeba zde připomenout alespoň osobnost a učebnici fyziologa Jiř́ho Prochásky (1749-1820), jehož život a dílo zhodnotil ve své monografii V. Kruta. Světově uznávaný je zejména př́nos J. Prochásky v oblasti výzkumu fyziologie nervstva, jeho pojetí nervového reflexu. Neurologickou tematiku nalézáme jak v učebnicích teoretických oborů (anatomie, fyziologie), tak i klinických. Jaké znalosti této problematiky byly vyžadovány při zkouškách z těchto oborů, nelze zjistit. Mezi profesory na pražské lékařské fakultě, s výjimkou zmíněného Prochásky, nebyl v oné době žádný, který by neurologii věnoval zvláštní pozornost. Také jen málokteří budoucí doktoři medicíny si ve svých disertacích volili neurologické téma. ${ }^{8}$

Od přelomu 30. a 40. let 19 . století se na pražské lékařské fakultě - podobně jako na ostatních lékařských fakultách v Evropě - setkáváme vedle profesorů a asistentů s novou kategorií učitelů, totiž s docenty. Asistentem mohl být každý pouze dvakrát dva školní roky, potom musel fakultu opustit. Získat profesorské místo bylo možno po úspěšném konkurzu, vítěz mohl zůstat na fakultě do sedmdesáti let. Ovšem oborů s řádnou profesurou bylo velmi málo, a proto vědecky orientovaní absolventi, kteří chtěli udržovat kontakt s fakultou, protože pouze $\mathrm{v}$ jejím rámci se mohli dále odborně a vědecky uplatňovat, si ve zmíněném období začali podávat žádosti o povolení konat jako docenti nepovinné přednášky, většinou z oborů dosud samostatně nekonstituovaných. Nutno říci, že pražská lékařská fakulta byla $\mathrm{v}$ tomto směru velice aktivní a $\mathrm{v}$ několika př́padech předběhla těmito přednáškami, v nichž se odrážela postupující specializace lékařských oborů, nejen vídeňskou, ale i ostatní evropské fakulty. ${ }^{9}$

Pokud se týče teoretických oborů, téměř s jistotou můžeme předpokládat, že s neurologickou problematikou se mohli seznámit posluchači mimořádných, později i řádných přednášek Vincenta A. Bochdalka (1801-1883), od roku 1840 mimořádného profesora patologické anatomie, od roku 1845 řádného profesora srovnávací a chirurgické anatomie. Bochdalek byl jedním z oněch mála mediků, kteří si zvolili neurologické, respektive anatomickoneurologické téma již své disertace (Anleitung zur praktischen Zergliederung des menschlichen Gehirnes nebst einer anatomischen Beschreibung desselben; mit besonderer Rücksicht auf das kleine Gehirn, Diss. Prag 1833). Bochdalek mnoho nepublikoval, ale několik svých studií věnoval právě nervovému systému a smyslovým orgánům. Některé termíny nesou jeho jméno - např. ganglion Bochdaleki. Neurologické problematice se věnoval zejména na počátku své vědecké dráhy.

Zatím se můžeme pouze domnívat, že v klinické výuce se neurologická problematika mohla objevit v mimořádných přednáškách z psychiatrie. Od školního roku 1841/42 je

8 Ludmila HLaváčKová - Petr SvoBodnÝ, Dějiny pražských lékařských fakult 1348-1990, Praha 1993, s. 22nn.; Ludmila HlavÁČKovÁ - Eva Rozsívalová, Studium a přednášky na lékařské fakultě pražské univerzity v letech 1690-1848, Praha 1984. Tam uvedeny názvy používaných učebnic, o nichž L. HLAvÁčKovÁ, Zjakých učebnic studovali posluchači pražské lékařské fakulty v prvé polovině 19. století?, AUC-HUCP 58/1, 2018, s. 69-83; srv. také Ludvík Schmid - Eva Rozsivalová, Pražské lékařské disertace, Acta Universitatis Carolinae (dále AUC) - Medica 1957, Praha 1957; Vladislav KRuTA, Med. Dr. Jiři Procháska 1749-1820. Život - Dílo - Doba, Praha 1956.

9 Přednášky jsme vypisovali z Ordnung öffentlichen ordentlichen und ausserordentlichen Vorlesungen, welche an der k.k. Universität zu Prag gehalten werden. Přednášky vycházely pod mírně a nepodstatně změněnými názvy vždy pro zimní a letní semestr. Nebudeme je opakovaně citovat, nebude-li to nutno. 
ohlašoval jako první v monarchii Josef G. Riedel (1803-1870), frýdlantský rodák, absolvent pražské lékařské fakulty, od roku 1837 pracovník, později primář a ředitel pražského ústavu choromyslných, od roku 1841 prvý docent psychiatrie $\mathrm{v}$ rakouském mocnářství. Byl nadán mimořádnými organizačními schopnostmi, zasloužil se mj. v roce 1844 o vybudování tehdy nejmodernějšího psychiatrického ústavu v rakouském soustátí (tzv. Nového domu) v blízkosti budovy bývalého augustiniánského kláštera, tehdy ústavu pro choromyslné (dnes sídla neurologické kliniky 1. LF UK v Kateřinské ulici). Obsah Riedlových přednášek bohužel neznáme, nevíme tedy, zda $\mathrm{v}$ nich zmiňoval i problematiku neurologickou. Na pražské fakultě ohlašoval přednášky až do roku 1851, kdy byl povolán do Vídně jako ředitel tamního ústavu choromyslných. ${ }^{10}$

Velmi významným počinem několika těchto průbojných a organizačně schopných představitelů pokrokových směrů na pražské fakultě (někdy se hovoří o této době jako o Pražské lékařské škole), bylo založení fakultního časopisu. Nepř́liš přiléhavý název zněl Vierteljahrschrift für die praktische Heilkunde, protože to byl časopis opravdu vědecký, přinášející vedle rozsáhlých původních studií i velmi cenné informace o světové odborné produkci ze všech oborů. Vycházel od roku 1844; ve svých rejstř́ících pro léta 1844-1866 heslo neurologie sice nemá, ovšem prací o nervech a nervovém systému uvádí velké množství. ${ }^{11}$

\section{Od roku 1848 do rozdělení pražské lékařské fakulty na českou a německou v roce 1883}

Revoluční léta 1848/49 přinesla evropským zemím řadu reforem mj. i v oblasti školství. Pro univerzity rakouské monarchie to byla především zásada „Lehr- und Lernfreiheit“ (svoboda vyučování a učení se). Nepochybně správná zásada poněkud zkomplikovala práci historiků. Zrušení povinných učebnic jim ztěžuje možnost učinit si představu o tom, jak se měnila a zkvalitňovala odborná př́prava medikủ. Na lékařských fakultách byla také zrušena povinnost předložit a obhájit disertaci.

V roce 1872 vyšel nový rigorózní rád pro lékařské fakulty. Místo dosavadních specializovaných titulů pro absolventy lékařských fakult (Med. Dr., Chir. Dr., magistr chirurgie, porodnictví) byl zaveden jednotný - dodnes použivaný - titul MUDr. (medicinae universae doctor). Řád také stanovoval, z jakých oborů musí medici skládat tři rigorózní zkoušky.

Neurologie jako samostatný předmět se $\mathrm{v}$ něm nevyskytuje, ale není pochyb, že otázky $\mathrm{z}$ neurologické problematiky se objevovaly $\mathrm{v}$ rámci prèedmětů prvého rigoróza $\mathrm{v}$ anatomii či fyziologii (z těchto oborů byla i zkouška praktická), v rámci druhého pak v patologické anatomii a vnitřním lékařství. Předpokládáme, že $\mathrm{v}$ těchto oborech jim byla věnována pozornost $\mathrm{v}$ hlavních přednáškách úměrně $\mathrm{k}$ tomu, jaký odborný zájem o ně měl přednášející. Psychiatrie nebyla rigorózním předmětem. Neurologickou problematiku je proto třeba hledat dále ve specializovaných, nepovinných přednáškách. ${ }^{12}$

10 Eugen Vencovskŕ, Sto let české psychiatrické kliniky v Praze 1886-1986, Praha 1987, s. 32-40; Cyril KneIDL, Př́spěvek $k$ dějinám péče o choromyslné v Čechách 1790-1890, in: Antonín Heveroch - František S. Frabša (edd.), Zemské ústavy pro choromyslné v Čechách, Jičín 1926, s. 21-30.

11 Ludmila HLAVÁČKOVÁ, Časopisy vydávané v minulosti pražskou lékařskou fakultou, Sborník lékařský 75, 1973, s. 120-134; Vierteljahrschrift für die praktische Heilkunde. Vollständiges Sach- und Namenregister über Jhg. 1844-1853, Prag, Verlag von Karl André, 1855; dtto pro léta 1854-1858, Prag 1858, a léta 1859-1863, Prag 1864.

12 L. HlaváčKovÁ - P. SvobodnÝ, Dějiny pražských lékařských fakult, s. 60-61. 
Pokud se týče anatomů, V. Bochdalek nazýval své mimořádné přednášky od roku 1851 nauka o smyslových orgánech, neuro- a angiologii, až do svého odchodu na odpočinek $\mathrm{v}$ roce 1871 . Hodinové přednášky konal pětkrát $\mathrm{v}$ týdnu v Karolinu v anatomické posluchárně. Jejich obsah také bohužel neznáme. Nevíme také, jakou pozornost věnovali neurologii ve svých hlavních přednáškách Bochdalkovi nástupci na katedře anatomie - Philipp Henke (1834-1896) a slavný Karl Toldt (1840-1920). Víme, že se sice badatelsky neurologií zvláště nezabývali, ale jak uvedeme dále, prvý z nich ohlásil specializovanou přednášku s neurologickou tematikou.

Mnohem větší pozornost věnovali neurologii ve svých základních přednáškách fyziologové. V prvé řadě nutno samožrejmě připomenout osobnost našeho největšího biologa a lékaře, profesora fyziologie, Jana E. Purkyně (1787-1869), který se navrátil na pražskou lékařskou fakultu $\mathrm{z}$ Vratislavi v roce 1850. S jeho objevy a postřehy se setkáváme v řadě biologických a lékařských oborů neurologii nevyjímaje (např. objev gangliových buněk v mozku, objev výběžků nervových buněk, rozlišení nervových vláken s různým fyziologickým významem, nervové řízení žaludeční sekrece aj. ${ }^{13} \mathrm{~V}$ jakém rozsahu se věnoval v rámci svých fyziologických přednášek neurologii, nevíme. Na sklonku svého života se často nechal zastupovat svým oddaným žákem docentem Františkem Novotným (1839-1879). Jako Purkyně i on se snažil zavádět do přednášek český jazyk. Publikoval málo (14 článků, žádný neurologický), ale v nepovinných přednáškách českých i německých ohlašoval někdy i témata neurologická (letní semestr 1873, zimní semestr 1876/77, letní semestr 1879 - histologie nervstva, česky „tkaninosloví“; tento výraz patrně sám vymyslil, dobové slovníky jej neuvádějí).

Také Purkyňův nástupce, Maxmilian H. Vintschgau (1832-1913), který na pražské fakultě působil jen tři roky (1867-1870), se badatelsky velmi úspěšně zaměřoval na fyziologii nervů a smyslových orgánů. Vystřídal ho Ewald Hering sen. (1834-1918), který se mj. zabýval psychofyziologií a elektrofyziologií. V jeho pražské laboratoři pracoval i slavný anglický neurolog Henry Head (1861-1940). Jeho nástupce a žák, fyziolog a histolog Sigmund Mayer (1842-1910) patrně ve své kmenové přednášce věnoval neurologické problematice př́slušnou pozornost, protože ta patřila $\mathrm{k}$ jeho hlavním badatelským zájmům, jak je zřejmé i z jeho bibliografie. Objevil napřr růstový konus na nervech. Jak uvedeme níže, nabízel posluchačům i specializované neurologické přednášky.

Jakou pozornost věnovali neurologii klinici - internisté ve svých základních přednáškách, nelze zjistit, protože nedali svým posluchačům učebnice. Prof. Anton Jaksch (1810-1887) i prof. Josef Halla (1814-1887), přednostové I. a II. interní kliniky, v této době téměř nepublikovali.

Obrat'me nyní pozornost k mimořádným přednáškám, jejichž počet i rozmanitost ve sledovaném období velmi výrazně vzrostl. Neurologická tematika se v nich podle jejich názvu objevovala často a to jak u teoretiků, tak u kliniků. Většinou to byly sobotní jednohodinové přednášky označované jako „publicum“, určené nejen medikům a lékařům, ale př́padně i širší veřejnosti. Konali je jak profesoři, tak i docenti.

13 Richard Rokyta, Purkyňovy studie o nervové tkáni a nervovém systému, in Eliana Trávníčková (ed.), Jan Evangelista Purkyně. Život a dílo. Sborník vydaný při příležitosti 200. výročí Purkyňova narození, Praha 1986, s. $248-254$. 
Z teoretiků to byl již zmíněný anatom Phil. Henke (1834-1897), který stál v letech 1872-1875 v čele pražského anatomického ústavu. Ohlásil v letním semestru 1872 přednášku o smyslech a nervech, ale publikačně se této problematice nevěnoval.

Také již uvedený Ewald Hering sen. (1834-1918) ohlásil svoji přednášku o fyziologii nervů a smyslových orgánů pouze jednou v zimním semestru 1871/72.

Nejsoustavněji přednášel o neurologických tématech zmíněný fyziolog S. Mayer. Zaměřoval se zejména na fyziologii vasomotorického nervového systému a histologii periferních nervů. Své přednášky ohlašoval od zimního semestru 1872/3 do letního semestru 1880 . Konal je ve fyziologickém ústavu a byly spojeny s pokusy.

Patologický anatom Hans Eppinger (1845-1916) ohlásil přednášku o patologické anatomii nervového systému (třikrát týdně hodina v patologickém ústavu) ještě jako docent v letním semestru 1874, poté znovu až v letním semestru roku 1882 (dvě hodiny týdně). V jeho bohaté publikační činnosti témata neurologická nenalézáme.

Fyziolog Wilhelm Biedermann (1852-1929) konal své sobotní dvouhodinové přednášky o fyziologii centrálního nervového systému ve dvou zimních semestrech ve školních létech 1881/82 a 1882/83 ve fyziologickém ústavu. Po rozdělení fakulty na českou a německou $\mathrm{v}$ roce 1883 přešel na německou a zde, jak uvidíme, $\mathrm{v}$ těchto přednáškách pokračoval.

Klinici ohlašovali fakultativní přednášky s neurologickými tématy čím dále častěji. Některé byly ohlášeny pouze jednou - asi nevzbudily dost zájmu.

V letním semestru 1856 ohlásil jedenkrát přednášku o chorobách mozku profesor vnitřního lékařství zmíněný J. Halla (1814-1887). Jan Špot (1813-1888), docent vodoléčitelství a ortopedie, ohlásil svoji hodinovou přednášku na neděli v zimním semestru 1858/59. Nazval ji Hydriatika krve a nervové choroby.

Zmíněný internista A. Jaksch (1810-1887) svou přednášku ohlášenou na zimní semestr 1859/60 nazval jednoduše - O nervových chorobách. Téměř za 10 let vypsal v zimním semestru 1868/69 přednášku nazvanou $O$ chorobách mozku $s$ demonstracemi u li̊žek nemocných, čímž zřejmě jako prvý zahájil u nás klinickou výuku neurologie. V zimním semestru 1873/4 vypsal znovu přednášku o nervových chorobách s demonstracemi. V letním semestru 1878 nabídl posluchačům přednášku o nervových chorobách podmíněných psychicky. Sobotní hodinové přednášky konal ve všeobecné nemocnici na své první interní klinice, kterou řídil od roku 1850 až do svého odchodu na odpočinek v roce 1881. Mezi 17 citacemi jeho publikací najdeme jednu věnovanou neurologické problematice. Na sjezdu německých lékařů, který se konal v roce 1863 v Karlových Varech, přednesl a poté publikoval studii o onemocnění periferních nervů.

Soustavně přednášel o neurologii docent Robert Väter (1830-1893), který byl v roce 1861 habilitován u nás jako prvý docent fyzikální terapie. Přednášel od zimního semestru 1861/62 až do letního semestru 1879 o fyzikálním léčení nervových a svalových chorob. Také on uváděl u názvu přednášky, že je spojena s demonstracemi u lůžka nemocných ve všeobecné nemocnici - tedy opět klinická výuka, v tomto př́ípadě již dlouhodobá, systematická. Väter publikoval málo, ale všechny jeho čtyři statě pojednávaly o elektroterapii. $\mathrm{V}$ roce 1872 se jednalo o jeho profesuře, údajně z politických důvodů neúspěšně. Nic bližšího se o těchto důvodech zatím nepodařilo zjistit.

Pouze jedinkrát - v zimním semestru 1864/65 - ohlásil hodinovou přednášku ve všeobecné nemocnici o chorobách nervového systému tehdy docent, od roku 1866 mimořádný profesor vnitřního lékařství, který si v roce 1877 rozšíruil specializaci na dětské 
lékařství - Josef Kaulich (1830-1886). Žádná z jeho nečetných prací (19) se nevěnuje neurologii.

Významný pražský internista, uznávaný i v zahraničí, Alfred Přibram (1841-1912), pokryl svými publikacemi tematicky v podstatě celou internu. V jeho bibliografii jsme překvapivě nenašli neurologickou problematiku, ačkoliv přednášky o ní vypisoval ještě jako docent, poté jako profesor (1873), od letního semestru 1871 do zimního semestru 1879/80. Konal je na interním oddělení všeobecné nemocnice většinou 2 hodiny v týdnu. Názvy obměňoval: choroby nervového systému, systematické přednášky o chorobách nervového systému, nemoci mozku a míchy; od letního semestru roku 1874 doplňoval název informací - „s ohledem na elektroterapii““. V roce 1883 přešel na německou lékařskou fakultu.

Theodor Petrina (Petřina) (1842-1928), další pražský proslulý profesor vnitřního lékařství, se už věnoval problematice nervových chorob (napřr. lokalizaci nervových onemocnění a neurózám) jako své hlavní specializaci jak v publikacích (monografie Die Neurastenie und ihre Behandlung, Berlin 1889), tak v přednáškách. Přednášky - většinou jednu hodinu týdně - konal ve všeobecné nemocnici soustavně od letního semestru 1873 do konce námi sledovaného období. Také on je spojoval s výklady o elektroterapii a pokračoval v nich i poté, co přešel na německou lékařskou fakultu.

Pražský rodák, Otto Kahler (1849-1893), světově uznávaný internista (např. Kahlerova choroba - myeloma multiplex), se proslavil i svými pracemi neurologickými. Prošel pražskou lékařskou fakultou od studentských let až po získání profesury, aby se od roku 1889 stal ozdobou vídeňské fakulty. Jako docent vypisoval v zimním semestru 1878/79 dvě přednášky; zřejmě všeobecnějšího zaměření byla ona o použití elektřiny v medicíně (hodinu týdně ve všeobecné nemocnici na II. interní klinice) a tamtéž se konal praktický dvouhodinový kurz elektroterapie s klinickými demonstracemi. O rok později (v zimním semestru 1879/80) rozšíril praktický kurz o využití elektřiny v medicíně na 20 hodin a vedle toho ohlásil přednášku (dvouhodinovou) o nemocech míchy opět s klinickými demonstracemi na zmíněném interním oddělení ve všeobecné nemocnici. Mnoho svých originálních studií uveřejnil v pražských lékařských časopisech (Vierteljahrschrift für die praktische Heilkunde, Zeitschrift für Heilkunde, Prager medizinische Wochenschrift). Spolupracoval s neméně proslulým pražským psychiatrem a neurologem Arnoldem Pickem (1851-1924). Jejich společný objev, Kahler-Pickův zákon, popsali v prvním z výše uvedených časopisů v roce $1879 .{ }^{14}$ Také Kahler pokračoval ve svých neurologických přednáškách na německé lékařské fakultě.

Arnold Pick (1851-1924) se habilitoval na pražské fakultě z psychiatrie a neurologie $\mathrm{v}$ roce 1878 a hned na sebe upozornil vědeckou veřejnost jako spoluautor zmíněného významného objevu. O jeho dalším velmi úspěšném vědeckém působení se zmíníme v následující kapitole. Své docentské přednášky konal v patologickém ústavu s názvem diagnostika mozkových chorob. ${ }^{15}$

Z uvedeného přehledu přednášek s neurologickou tematikou je zřejmé, že se jí věnovali z kliniků především internisté. Psychiatrie byla ve sledovaném období v rámci lékařských oborů ještě neprŕiliš vědecky fundovaná, a proto se netěšila valné vážnosti. Nevíme, kdy

14 Erna Lesky, Die Wiener medizinische Schule im 19. Jahrhundert, Graz - Köln 1965, s. 326-327; Otto KAHLER - Arnold PICK, Beiträge zur Pathologie und pathologischen Anatomie des Centralnervensystems, Vierteljahrschrift für die praktische Heilkunde 36/142, 1879, s. 1-101.

15 Ludmila HLAVÁČKOVÁ, Česká a německá psychiatrická klinika pražské lékařské fakulty do roku 1918, I, in: Karel Černý - Petr Svobodný (edd.), Historia, medicina, cultura, Praha 2006, s.133-162. 
vznikl známý aforismus, tradovaný nejméně v předminulém století, o tom, že chirurgové hodně mohou, ale nic nevědí, internisté mnoho vědí a nic nemohou a psychiatři nic nevědí a nic nemohou... ${ }^{16}$

Na závěr této kapitoly si položme otázku, kdy se začala pěstovat neurologie českým jazykem.

V zápase o českou univerzitu a v jejím rámci českou lékařskou fakultu sehráli čeští lékaři a medici nezastupitelnou úlohu. Využili politického uvolnění na počátku 60. let 19. století a v roce 1862 založili Časopis lékařu českých (ČLČ) a Spolek českých lékařù. Čeští medici si založili hned příští rok nejprve Klub mediků českých jako soukromé sdružení, který se v roce 1868 změnil na veřejnou společnost s názvem Spolek českých mediků. V rámci těchto institucí se odehrával dlouholetý zápas o českou univerzitu. Po úmrtí J. E. Purkyně (1869) jej vedl především internista profesor Bohumil Eiselt (1831-1908), který důsledným vyhlašováním českých přednášek od roku 1861 jako prvý dosáhl toho, že mu bylo v červnu 1871 povoleno zř́dit ve všeobecné nemocnici první českou kliniku.

Na stránkách ČLČ také nalezneme prvé české př́spěvky o neurologii. V letech 1862-1882 se zde setkáme vedle psychiatrickoneurologických kasuistik několika terénních lékařu především se jmény dvou významných vídeňských profesorů, rodáků z českých zemí, kteří se proslavili svými neurologickými pracemi. Jsou to učitel a žák, Vojtěch Duchek (1824-1882) a František Chvostek (1834-1884). Prvý, pražský rodák a absolvent pražské lékařské fakulty, působil od roku 1857 jako profesor vnitřního lékařství na vídeňském Josefinu, proslulé lékařské fakultě pro výchovu vojenských lékařů, od roku 1870 pak na vídeňské lékařské fakultě. Proslavil se zejména objevy v oblasti výměny látkové a nervových chorob. F. Chvostek, rodem z moravského Místku, studoval na Josefinu. Zde ho Duchek v roce 1867 habilitoval a posléze se zde stal Duchkovým nástupcem jako profesor elektroterapie a speciální lékařské patologie a terapie (dnes vnitřní lékařství). Proslavil se zejména poté, když v roce 1878 popsal symptomy zvýšené dráždivosti lícního nervu, tzv. Chvostkův př́znak. ${ }^{17}$

V ČLČ vyšla v roce 1873 rozprava o atrofii mozku pod názvem $Z$ medicinské kliniky prof. dr. Vojtěcha Duchka, bez autora, patrně od něho samého, nebo určitě s jeho svolením. ${ }^{18} \mathrm{~V}$ následujícím roce pak zde nalezneme v osmi pokračováních rozsáhlou Chvostkovu studii $O$ vstřebavém pưsobení proudu elektrického. ${ }^{19}$

Z uvedeného je zřejmé, že dva jmenovaní významní neurologové českého původu poskytli českým kolegům zřejmě ochotně možnost získat na stránkách ČLČ o neurologii spolehlivé informace.

V roce 1871 nalezneme v ČLČ zajímavý článek, bohužel anonymní, nazvaný Potřeba neurologického ústavu. Uvádí se v něm, že ve vídeňské všeobecné nemocnici bylo nedávno zrrízeno oddělení pro vyšetřování choromyslných, kteří by jinak skončili v blázinci. V nemocničním oddělení mají naději být pozorováni, ošetřováni a vyléčeni. (To se zřejmě nekonalo ani v blázinci vídeňském, ani v pražském). Krátký článek končí naléhavým přáním autora: „Kéž by také naše Praha měla bud’ svioj Ústav pro nemoci nervio, mozku atd.

16 Hans-Heinz Eulner, Die Entwicklung der medizinischen Spezialfächer an den Universitäten des deutschen Sprachgebietes, Stuttgart 1970, s. 257.

17 E. Lesky, Die Wiener medizinische Schule, dle rejstř́ku.

18 ČLČ 12, 1873, s. 184-186. V tomtéž čísle je referováno i o jiných chorobách na Duchkově klinice.

19 ČLC C 13, 1874, s. 113-114, 121-126, 133-135, 141-143, 149-152, 157-159, 166-169, 175-177. 
nebo alespoň zvláštní oddělení v nemocnici. “ ${ }^{20} \mathrm{~K}$ splnění tohoto prání vedla, jak uvidíme, ještě dlouhá cesta.

Nakonec ještě uved'me, že B. Eiselt začal již v roce 1863 jednat o tom, aby se začalo pracovat na vydání českého kompendia, které by informovalo o současném stavu poznatků v jednotlivých lékařských oborech. Sám se ujal redigování tohoto díla nazvaného Odborná pathologie a therapie, na kterém se autorsky podílely desítky českých lékařù, takže jeho odborná úroveň je dosti nevyrovnaná. Vycházelo po sešitech, první se objevil v roce 1878. Do roku 1889 vyšlo pět objemných dílů, šestý zůstal nedokončen. Eiselt chtěl v něm vydat souběžně i ,nemoci mozku a srdce“, ale bohužel k tomu nedošlo. Patrně hodlal svěřit tuto část právě A. Duchkovi, v té době přednostovi II. lékařské kliniky ve Vídni; Eiselt vzpomenul jeho úmrtí v předmluvě $\mathrm{k}$ IV. dílu, v níž nazval Duchka nenahraditelným.

Otázce pronikání češtiny do neurologických publikací věnoval pozornost tehdy docent neurologie Ladislav Haškovec (1866-1944), který na konci 90. let 19. století vyexcerpoval všechna tehdejší česká periodika, samostatné práce i práce českých autorů v zahraničních časopisech. ${ }^{21}$ Již jsme se zmínili o přednáškách J. E. Purkyně a jeho žáka J. Novotného, kteř́ přednášeli oběma zemskými jazyky (což bylo povoleno od revolučních let 1848/49), ostatní přednášky z neurologie byly v tomto období pouze německé.

\section{Neurologie na české lékařské fakultě od roku 1883 do 30 . let 20 . století}

Vítězný zápas o českou univerzitu skončil vydáním zákona o rozdělení pražské univerzity na českou a německou z 28. 2. 1882. Vznikly dvě zdánlivě rovnoprávné univerzity. Zákon totiž stanovil, že ústavy, sbírky, knihovny a kliniky zůstanou té univerzitě, pro kterou se rozhodne její stávající přednosta. Na lékařské fakultě měli v profesorském sboru výraznou převahu členové hlásící se $\mathrm{k}$ německé národnosti. Ti si záměrně vybírali asistenty mezi německými uchazeči a ty také habilitovali. Nutno si uvědomit, že ve srovnání s fakultou filozofickou a právnickou se velmi obtížně vytvářela odborná lékařská terminologie a jen nemnozí byli schopni česky přednášet na lékařské fakultě na potřebné úrovni. Pro přechod na českou fakultu se rozhodli vedle Eiselta pouze chirurg Vilém Weiss (1835-1891) a porodník Jan Streng (1817-1887). Největší obtíž byla s umístěním a obsazením teoretických ústavů. Velké moderní ústavy vybudované v druhé polovině 19. století, patologický (1859), anatomický (1877) a chemický (1879) v ulici U Nemocnice připadly německé fakultě. Pro české teoretické ústavy byla narychlo - za pouhý půlrok od dubna do října 1883 - vystavena první část budovy v Kateřinské ulici, kde se tísnilo sedm ústavů. Při tom je třeba si uvědomit, že na německé fakultě zbyla zhruba pouhá třetina posluchačů.

První roky existence české fakulty byly proto nepředstavitelně obtížné, ale chmurné předpovědi německých profesorů, že česká fakulta nebude mít dostatek posluchačů a potřebnou odbornou úroveň, se nevyplnily. Nejlépe obstála mladá generace učitelů české fakulty, jak teoretiků, tak kliniků. ${ }^{22}$

20 ČLČ 10,1871 , s. 288.

21 Ladislav HašKovec, Přehled českých prací z oboru neurologie a psychiatrie v letech 1848-1898, nákladem Spolku českých mediků, Praha 1899.

22 Ludmila HlaváČKOvÁ, Vybudováni teoretických ústavů české lékařské fakulty v l. 1883-1884, AUC - Historia Universitatis Carolinae Pragensis (dále AUC-HUCP) 22/1, 1982, s. 123-152; TÁž, Snahy o vybudování českých 
K nejznámějším z nich patří patolog Jaroslav Hlava (1855-1924) a internista Josef Thomayer (1853-1927), o něm budeme hovořit i níže. Na tomto místě jen uvedeme, že tito vrstevníci - kolegové a v mladých létech i přátelé - se krátce po aktivování české lékařské fakulty (v roce 1885) rozhodli vydávat vědecký časopis Sborník lékařský (pod poněkud obměňovanými názvy jej fakulta vydává dosud, od r. 2003 v anglické verzi jako Prague Medical Report) ${ }^{23}$, který měl umožnit publikovat především pracovníkům fakulty rozsáhlejší vědecké studie, které nebylo možno dát do ČLČ. Tím nejlépe dokázali, že mladá česká fakulta učiní vše, aby udržela svoji úroveň na výši doby. Je př́iznačné, že resumé v něm byla francouzská. Na jeho stránkách nalezneme i řadu neurologických studií z per teoretiků i kliniků.

Thomayer také založil v roce 1888 známou Sbírku přednášek a rozprav z oboru lékařského, v níž vycházely rozsáhlejší studie či nevelké monografie. Do roku 1902 zredigoval sám 100 prvních čísel (poslední číslo 515 vyšlo v roce 1991).

Po stránce právních předpisů a studijních řádů se obě fakulty řídily stejnými normami. Nový rigorózní řád byl vydán až v roce 1899. Pro nás je důležité, že u třetího rigoróza se společně zkoušela poprvé psychiatrie, dětské lékařství a dermatovenerologie. Již za tři roky (1903) vyšel nový rigorózní řád pro lékařskou fakultu, který v podstatě platil i v meziválečném období. Při druhém rigorózu se jako samostatné obory zkoušela vedle dětského lékařství a psychiatrie poprvé i neuropatologie. ${ }^{24}$ Tímto zkušebním řádem byla psychiatrie a neuropatologie poprvé uznána v rakouském soustátí jako obligatorní učební a zkušební obor.

Co se čeští medici dozvídali o neurologii, se můžeme dozvědět především v učebnicích a potom opět v názvech mimořádných př̀ednášek. ${ }^{25} \mathrm{Z}$ teoretických oborů dostali čeští medici učebnice anatomie z pera Jana Janošíka (1856-1927). Jeho Histologie a mikroskopická anatomie (Praha, Bursík a Kohout 1892) obsahuje kapitolu Nervstvo a ve dvoudílné Anatomii člověka (Praha, Springer 1912-1913) je ve druhé části rozsáhlá kapitola Systém nervový.

Fyziolog Vladimír Tomsa (1831-1895), který přešel na českou lékařskou fakultu z kyjevské univerzity, vydal učebnici fyziologie v roce 1883 v Kyjevě. Čeští medici používali jeho litografované přednášky rozvržené do pěti částí. Pátá byla věnována fyziologii míchy a mozku.

Významný fyziolog, filozof ale i politik, František Mareš (1857-1942) uveřejnil svoji první Všeobecnou fyziologii v Praze 1894 vlastním nákladem. V letech 1906-1929 vyšla jeho čtyřdílná Fyziologie v šesti svazcích (Praha, Bursík a Kohout). V těchto publikacích

klinických pracovišt’ préed rozdělením univerzity, Sborník lékařský 85/4, 1983, s.105-115; TÁž, Budování českých klinických pracovišt’ po rozdělení univerzity a lékařské fakulty, Sborník lékařský 85/5, 1983, s. 147-159.

23 L. HlavÁČKovÁ, Časopisy vydávané v minulosti, s. 120-134; TÁž, K výroči Sborníku lékařského, Sborník lékařský 89/10, 1987, s. 314-320.

24 Reichgesetzblatt für die im Reichsrathe vertretenen Königreiche und Länder. Stück CXIV, 31. December 1899, řád z 21. 12. 1899; Otto Placht - František HavelKa, Předpisy pro vysoké školy Republiky československé, Praha 1932, řád z 14. 4. 1903, s. 1785-1796.

25 Seznam přednášek, které se odbývati budou na c.k. České Karlo-Ferdinandské univerzitě v Praze v zimním (letním) semestru... (od zimního semestru 1883/4); od letního semestru 1919 Seznam přednášek, které budou se konati na České univerzitě Karlově v Praze. Německá fakulta: Ordnung der Vorlesungen an der k.k. Deutschen Carl-Ferdinands-Universität zu Prag - od zimního semestru 1883/4; Ordnung der Vorlesungen an der Deutschen Universität in Prag - od zimního semestru 1919/20. 
je pojednáváno i o neurologických otázkách. Výzkumně se zabýval např. elektrofyziologií nervového systému.

Všichni výše uvedení i několik dalších teoretiků ohlašovali i mimořádné přednášky s neurologickou tematikou. Jan Janošík ohlašoval v letech 1886-1889 speciální dvouhodinovou přednášku o histologii centrálního nervstva. Vladimír Tomsa ohlásil mimořádné neurologické přednášky na sklonku své akademické dráhy v letech 1891-1894. František Mareš naopak ohlašoval tyto přednášky na počátku svého učitelského působení v letech 1889-1898. Jen dva roky (1903-1905) je vypisoval fyziolog Edward Babák (1873-1926), od roku 1919 působící na nově založené Masarykově univerzitě v Brně. Anatom Otmar Völker (1871-1955), od roku 1919 působící tamtéž, vypisoval v letech 1907-1917 přednášky s jedním tématem - periferní nervy.

V období meziválečném (v letech 1932-1938), přednášel o mikroskopické anatomii centrálního nervového systému Jan Wolf (1894-1977), profesor histologie a embryologie. V zimním semestru 1933/34 konal profesor fyziologie Antonín Hanák (1889-1935) pětihodinové přednášky o fyziologii nervového systému a čidel, za rok poté o fyziologii nervstva a ústrojů s vnitřní sekrecí. Docent histologie a embryologie Vladimír Tůma (1897-1945) ohlásil v zimním semestru 1936/37 pětihodinovou přednášku o fyziologii nervstva a čidel spojenou s tříhodinovým cvičením. Docent anatomie Karel Žlábek (1902-1983) ohlásil hodinovou přednášku o anatomii vegetativního nervstva v letním semestru 1937. V tomtéž semestru vypsal tehdy docent anatomie Ladislav Borovanský (1897-1971) hodinovou přednášku o anatomii nervů cerebrospinálních. Biolog Bohumil Krajník (1895-1966) nabízel dvouhodinovku o vztahu biologické konstituce člověka k projevům duševním v zimním semestru 1937/38. Tehdy docent fyziologie Vladislav Kruta (1908-1979) mohl svoji ohlášenou dvouhodinovou přednášku o obecné fyziologii nervstva konat v zimním semestru 1939/40 pouze několikrát, 17. listopadu 1939 byly české vysoké školy zavřeny německými okupanty a V. Krutovi se podařilo uprchnout do Anglie.

Podívejme se nyní, jaká pozornost byla věnována neurologii v prvých českých učebnicích vnitřního lékařství. Napsali je přednostové obou interních klinik. V čele první stál do roku 1902 vícekrát zmíněný B. Eiselt, který ji předal svému zeti Emerichu Maixnerovi (1847-1920); jenž do té doby ř́idil druhou interní kliniku. Jejího vedení se po něm ujal Josef Thomayer (1853-1927).

V roce 1887 začal vydávat E. Maixner svoji čtyřdílnou učebnici pod názvem Příruční kniha speciálni pathologie a therapie vnitřnich nemoci (Praha, Bursík a Kohout 1887-1895). Čtvrtý díl nazvaný Nemoci perifernich nervi̊, michy a jejich plen (594 stran) měl téměr̆ o dvě třetiny více stran, než věnoval v prvním vydání své učebnice neurologii Thomayer. Je zajímavé, že v publikacích o Maixnerovi se zdůrazňují především jeho práce věnované kardiologii, problematice TBC, nemocem hrtanu aj., ale neurologie se nezmiňuje. Maixner neuvádí literární podklady své práce a nemá v ní poznámkový aparát.

Thomayerova Patologie a therapie nemocí vnitřnich vyšla v roce 1893 (Praha, Bursík a Kohout). Měla 726 stran a $\mathrm{z}$ toho neurologii bylo věnováno ve čtyřech oddílech nazvaných Nemoci mozku a jeho plen, Nemoci míchy a jejích plen, Nemoci nervů obvodových a Nervosy celkem 183 stran. V dalších vydáních Thomayer toto své základní dílo doplňoval. V pátém vydání z roku 1923 již měly Nemoci soustavy nervové o 85 stran více. Kniha je bez vyobrazení, bez poznámkového aparátu. Jen velmi zř́́dka je v textu uvedeno jméno nějakého autora bez uvedení publikace, $v$ níž by se našel jeho autentický názor. 
Zajímavé ovšem je, že Maixner ohlásil pouze ve třech letních semestrech (1900, 1901, 1902) specializovanou jednohodinovou přednášku Povšechná a specializovaná patologie chorob mozkových a poté již se touto problematikou zřejmě nezabýval.

Naproti tomu Thomayer zahájil své dvou až tříhodinové přednášky o patologii a terapii nemocí nervových spojené s cvičením ve vyšetřovacích metodách a elektroterapii hned rok po aktivování české fakulty - v letním semestru roku 1884 - a konal je nejprve ve všeobecné nemocnici na oddělení prof. Eiselta, poté, co byl jmenován přednostou fakultní polikliniky, od zimního semestru školního roku 1887/88 do zimního semestru 1904, na její půdě (do roku 1888 byla umístěna ve Vladislavově ulici č. 43, poté ve Vodičkově ulici v č. 674 v domě nazývaném U Hopfenštoků). V letním semestru roku 1888 a znovu po 16 letech - v letním semestru 1904 - konal Thomayer hodinovou přednášku nazvanou Bezvědomí. Tato vyšla i jako samostatná publikace. ${ }^{26} \mathrm{Na}$ to, jak probíhala Thomayerova výuka u Hopfenštoků, vzpomíná ve svých nepublikovaných pamětech jeden z jeho nejvýznamnějších žáků, Josef Pelnář (1872-1964). „Poliklinika byla na prvním patře u Hopfenštoků v několika mistnostech. Prvni široká místnost byla čekárna, druhá větší místnost byla posluchárna s židličkami a tabulí. Vedle posluchárny byl dost veliký pokoj, kde měl Thomayer různé predměty a některé pristroje. Za ním byl malý jednooknový pokoj ordinačni a proti jeho dveřim byl vchod do jakési úpravny, kde demonstrátor sepisoval chorobopisy docházejících pacientů. V pokoji ordinačním před oknem byl stůl, kde byly čisté chorobopisy a tlustá kniha, kam se zapisovali všichni přednášející. U tohoto stolu seděli dva lékaři. U podélné stěny vpravo vedle stolu až ke dveř́m do úpravny byla pohovka pro Th. a souseda. Většinou tam sedával starý Skalička, eventuálně nějaký host. U protějši podélné stěny byly židle pro doktory (pět až šest). Proti Th. byl stůl, kde se vyšetřovaly moče a jiná zkumadla (dr. Červenka), vedle něho umyvadlo a štandlik. To až ke dveřim, jimiž se vcházelo z posluchárny pracovnou do ordinace. Vzadu na konci pokoje v rohu byla temná komora, kde se vyšetřovalo oftalmoskopem s krčními a ušními sluchátky. Nepamatuji se už, kteři doktoři tam seděli, když jsem přišel, protože jsem byl na poliklinice až do 1901, pamatuji si dobře všechny kolegy, kteři tam seděli řadu let a mezi nimiž se nám utvořilo vlastní společné prostředi “" $27 \mathrm{Z}$ uvedeného je ovšem zřejmé, že Thomayerových poliklinických specializovaných přednášek se zúčastňovali především již hotoví lékaři, a byly to tedy dnešní terminologií řečeno postgraduální „doškolovací“ semináře. Když Thomayer stanul v čele II. interní kliniky a začal týdně přednášet hlavní desetihodinovou přednášku z vnitřního lékařství, ohlásil v letním semestru 1904 naposledy zmíněnou přednášku o bezvědomí a poté již specializované přednášky nekonal.

Thomayerova souhrnná bibliografie dosud bohužel nebyla zpracována, uvádí se, že je autorem několika set odborných prací uveřejňovaných převážně v českých periodikách. Vedle toho, jak známo, zanechal rozsáhlé dílo beletristické. ${ }^{28}$ Zabýval se vnitřním lékařstvím v celém jeho rozsahu, ale neurologická problematika ho zajímala od samého počátku jeho vědecké dráhy. Zabýval se jí v desítkách studií a je mu připisována řada priorit;

26 Josef Thomayer, Bezvědomi a jeho diagnostický význam. Vyňato z přednášek v letním běhu r. 1888 odbývaných. V Praze, Nakl. Bursík a Kohout s.d.

27 Pelnářovy paměti jsou uloženy v jeho osobním fondu v Masarykově ústavu a Archivu AV ČR, kart. 1, s. 24.

28 Zatím stále nejpodrobnější je výčet Thomayerových prací v biografické př́ručce Michal NAVRÁTIL, Almanach českých lékařĭ, Praha 1913, s. 328-331. 
některé byly nazývány jeho jménem, např. Thomayerův syndrom obrny kořenové. ${ }^{29}$ Proto bývá nazýván naším prvním neurologem. Nenalezla jsem zmínky o tom, že by Thomayer usiloval o vyčlenění neurologie z vnitřního lékařství jako samostatného oboru, ani o tom, že by na své klinice vyčlenil li̊žka pro neurologické pacienty.

Od sklonku 90. let 19. století přibývá v seznamech přednášek neurologická problematika v klinických oborech. Specializované přednášky nabízejí především internisté. Opět vidíme, že někteří vypisovali tyto přednášky jen velmi krátce, jiní naopak po řadu semestrů. Připomeňme je v chronologickém pořadí, jak se objevovaly na stránkách seznamů přednášek.

První přednášku nazvanou Choroby mozku vypsal brzy po rozdělení fakulty v zimním semestru 1886/87 mladý, velmi erudovaný docent dětského lékařství Josef Zít (1850-1887), který však již 31. ledna roku 1887 zemřel. Významný internista, Václav Libenský (1877-1938), Thomayerův žák, šel ve šlépějích svého učitele, když po habilitaci z vnitřního lékařství v roce 1909 od letního semestru 1910 do letního semestru 1920 (od roku 1916 s titulem mimořádného profesora) přednášel na fakultní poliklinice dvou až tř́hodinový Úvod do studia nervových chorob s demonstracemi prípadů a metod vyšetrovacich. Těžiště jeho vědeckého zájmu se ale přesunulo především na kardiologii. Nejoblíbenější Thomayerův žák, Josef Pelnář, sice ohlásil pouze v jednom zimním semestru 1910/11 na jeho klinice hodinovku Drobné zjevy neuropatologické, ale svými publikacemi se stal jedním ze spoluzakladatelů neurologie u nás. Jeho monografie Třes ve svých tvarech, podstatě a klinické ceně (Praha, Bursík a Kohout 1912) vyšla o rok později v Berlíně v německém překladu (Das Zittern, Berlin 1913). Mimo jiné byl Pelnář také jedním ze spoluzakladatelů Purkyňovy společnosti pro studium duše a nervstva. ${ }^{30}$

Zajímavě zaměřil své přednášky František Procházka (1864-1934), v roce 1904 habilitovaný z vnitřního lékařství, který v roce 1912 získal titul mimořádného profesora pro vnitřní, úrazové a sociální lékařství. V zimním semestru 1913/14 nabízel hodinovou přednášku Nervové nemoci ve stárí, a poté vždy v letním semestru od roku 1914 do roku 1919 opět hodinu Nemoci nervové po úrazu.

Známý balneolog, revmatolog a představitel fyzikální medicíny Eduard Cmunt (1878-1967) zahájil hned po své habilitaci z balneologie v roce 1917 dvouhodinové přednášky O fyzikálně dietetické léčbě chorob srdečních, cévních a nervových. S poněkud obměněnými názvy konal tyto přednášky - od roku $1928 \mathrm{~s}$ titulem mř. profesora - do zimního semestru 1931/32, poté se věnoval především revmatologii, organizaci našeho lázeňství aj.

V meziválečném období ohlásili dva oftalmologové přednášky s oftalmologicko-neurologickou tematikou. Jen jedinkrát - v letním semestru 1926 - vypsal Josef Janků (1886-1963), v roce 1923 habilitovaný z očního lékařství (od r. 1955 profesor Lékařské fakulty hygienické) hodinovou přednášku Diagnostický význam patologie terče čivu zrakového pro internistu a neurologa. Soustavněji se této mezioborové tematice věnoval Jaromír Kurz (1895-1965), v roce 1929 habilitovaný z očního lékařství (od roku 1945 profesor

29 MUDr. Pavel Čech, který se zabývá lékařskými eponymy, mi laskavě sdělil, že udělal rešerši v devíti publikacích o eponymech; Thomayerovo jméno $\mathrm{v}$ nich našel čtyřikrát $\mathrm{v}$ souvislosti s peritonitidou a dvakrát $\mathrm{s}$ jeho hmaty testujícími páteř. Více o Thomayerově profesní dráze Ludmila HLAVÁčKOVÁ, Druhá česká a německá interni klinika v Praze v dobách přednostenství E. Maixnera, J. Thomayera a R. Jaksche, AUC-HUCP 51/2, 2011, s. 11-43.

30 Pelnářova bibliografie vyšla několikrát v ČLČ: 61, 1922, s. 1041-1051; 81, 1942, s. 1267-1272; 91, 1952, s. $1266-1272$. 
a přednosta II. oční kliniky). Na oční klinice přednášel dvě hodiny o neurologii oka vždy v zimním semestru od roku 1933/34 až do zavření českých vysokých škol 17. listopadu 1939.

Nyní se podívejme, jakou pozornost věnovali neurologii psychiatři. Autorem první české učebnice psychiatrie je Karel Kuffner (1858-1940), který se v roce 1891 habilitoval pro všeobecnou, speciální i soudní psychiatrii a neurologii. V roce 1895 dostal titul suplujícího profesora a suplujícího přednosty psychiatrické kliniky. Řádnou profesuru a přednostenství získal v roce 1900. První díl své učebnice Psychiatrie pro studium i praktickou potřebu lékaře, publikoval ještě jako docent. Druhý díl byl charakterizován jako speciální. Profesor Vondráček se o této učebnici vyjádřil, že byla „překrásná“. ${ }^{31}$ Ve srovnání s učebnicemi vnitřního lékařství je $\mathrm{v}$ této věnována neurologii jen malá pozornost.

V chronologické posloupnosti ted’ uvedeme, kdo z psychiatrů ohlašoval přednášky s neurologickým zaměřením a kdo se z neurologie habilitoval.

K. Kuffner až do svého odchodu na odpočinek v roce 1929 ohlásil pouze čtyřikrát mimořádné přednášky s neurologickou tematikou. Poprvé to bylo v letním semestru 1897, kdy denně nabízel Praktická cvičení v průzkumu nervstva centrálního, v letním semestru 1901 a 1902 Praktická cvičení v histologii centrálního nervstva (8h. „,budou-li získány místnosti“) a poté až na sklonku své pracovní dráhy, v zimním semestru 1927/28 a 1928/29, Patologii a terapii chorob duševních a s nimi nervových.

V letním semestru 1897 vypsal poprvé hned dvě přednášky neurologického obsahu také Ladislav Haškovec (1866-1944), zakladatel naší první neurologické kliniky, kterému budeme věnovat zvláštní pozornost po dokončení tohoto přehledu.

Od zimního semestru 1900/01 zahájil své neurologické přednášky Antonín Heveroch (1869-1927), mimořádná osobnost dějin naší psychiatrie a neurologie. Habilitován byl z psychiatrie a neurologie na sklonku roku 1899 (20. 12.), tři roky po L. Haškovcovi. V roce 1904 založil a vedl v rámci fakultní polikliniky neurologickou ambulanci. Titul mimořádného profesora získal v roce 1906; 1909 byl prohlášen skutečným mimořádným profesorem a v roce 1921 řádným profesorem. Od roku 1919 byl vrchním ředitelem Zemského ústavu pro choromyslné v Praze. Tuto funkci zastával až do své smrti. V roce 1924 dosáhl toho, že jeho oddělení v tomto ústavu bylo prohlášeno za druhou psychiatrickou kliniku, ovšem pouze ad personam, s jeho smrtí její krátká existence skončila. V roce 1919 stál u zrodu naší druhé odborné lékařské společnosti, která byla nazvána Purkyňova společnosti pro studium duše a nervstva. ${ }^{32} \mathrm{~V}$ neurologii se věnoval především problémům blízkým psychiatrii (afasie, alexie, agrafie, agnosie, skalkulie, apraxie, amuzie). ${ }^{33}$

Heveroch ohlašoval své speciální neurologické přednášky od zimního semestru 1900/01 až do své smrti - zemřel 2. 3. 1927 - jeho přednášky byly ohlášeny i na letní semestr 1927, který však již nedokončil. Názvy přednášek - většinou jednohodinových - shrneme do několika okruhů: první přednáśka ohlašovaná čtyři semestry byla svým způsobem jedinečná - Heveroch ji věnoval nádorům centrálního nervstva. $V$ dalších se věnoval anatomii

31 Karel Kuffner, Psychiatrie pro studium i praktickou potřebu lékaře, I, Část povšechná, Bursík a Kohout, Praha 1897, II, Část speciální, tamtéž, 1900; Vladimír VondRÁČEK, Lékař dále vzpomíná, Praha 1977, s. 135.

32 Karel ČERNÝ, Dějiny České psychiatrické společnosti a jejich predehůdkyň (1919-1979), Česká a slovenská psychiatrie 95/1, 2003, s. 27-44.

33 E. VencovskÝ, Sto let české psychiatrické kliniky, s. 92-96; Vladimír VondráčEK, Osobnost Antonína Heverocha (1869-1927) a jeho význam pro české védy psychologicko-psychiatrické, ČLČ 108, 1969, s. 571-574. 
centrálního nervstva, úvodu do klinické neurologie, klinickému vyšetřování nervových chorob a zejména jejich kasuistice. Do letního semestru roku 1919 přednášel na Maixnerově interní klinice, poté v Kateřinské ulici na psychiatrické klinice.

Zdeněk Mysliveček (1881-1974) se habilitoval z psychiatrie a neurologie v březnu roku 1917. Své docentské neurologické přednášky o všeobecné neurologické diagnostice, které také hodlal konat na Maixnerově klinice, uskutečnil patrně jen v letním semestru 1918, nebot' na počátku zimního semestru 1918/19 došlo k vyhlášení Československé republiky a Mysliveček dostal řádnou profesuru z psychiatrie a neurologie na nově založené Komenského univerzitě v Bratislavě. Na pražskou fakultu se vrátil v roce 1930, poté už neurologické přednášky neohlašoval.

Jan Janský (1873-1921), od r. 1914 mř. profesor psychiatrie, byl mj. přednosta neurologického a soudně psychiatrického oddělení pražské posádkové nemocnice. V letním semestru 1921 v ní konal tř́hodinovou přednášku nazvanou Neurologická ambulance a cvičení soudnè psychiatrická.

V zimním semestru 1922/23 zahájil své přednášky s neurologickou problematikou Leo Taussig (1884-1944, zahynul v Osvětimi), v roce 1919 habilitovaný z psychiatrie, který si v roce 1922 rozšriřil venia legendi na neuropatologii. Vypisoval je soustavně až do zavření českých vysokých škol nacisty v listopadu 1939. Názvy přednášek odpovídají jeho odbornému průkopnickému zaměření na likvorologii a serologii v diagnostice nervových chorob (významná monografie Liquor cerebrospinalis, Praha, M+L 1926); obecněji nazýval své přednášky Návod ku klinickému vyšetřování neurologickému. Konal je nejprve $\mathrm{v}$ ambulatoriu pro choroby nervové na Karlově náměstí 21, od roku 1924 v ústavu choromyslných v Kateřinské ulici.

V zimním semestru 1927/28 ohlásil svou první neurologickou přednášku, kterou hodlal konat na I. interní klinice prof. Syllaby, Kamil Henner (1895-1967). Bude mu věnována pozornost ve zvláštní kapitole.

Hubert Procházka (1885-1935) se habilitoval z neuropatologie a psychiatrie v roce 1928. Přednášel na psychiatrické klinice tři semestry (letní 1928, zimní 1928/29, letní 1930) o pyrogenní léčbě duševních a nervových chorob a o dignosticko-prognostickém výzkumu sera a likvoru duševních a nervových chorob.

Jan Šebek (1895-1959), vrstevník Hennerův, první asistent L. Haškovce, byl habilitován z neurologie ve stejném roce jako Henner - 1927. Oba již se věnovali výhradně neurologii. Šebek byl jmenován bezplatným mimořádným profesorem v roce 1933, ale svoji neurologickou kliniku získal až v roce 1956 na tehdejší Lékařské fakultě hygienické. Neurologické přednášky vypisoval soustavně od letního semestru 1928 až do zavření českých vysokých škol v listopadu 1939. Konal je na Haškovcově neurologické klinice na Karlově a byly zaměřeny dle názvů hodně prakticky (neurologické praktikum, neurologický seminář, klinika nervových chorob, vyšetřování a léčení nervových chorob apod.)

Jiř́ Vítek (1901-1974) se habilitoval z neuropatologie v roce 1933, mimořádné profesury se dočkal až po válce v roce 1946, rádné v roce 1966. Od letního semestru 1934 až do zavření českých vysokých škol ohlašoval přednášky, většinou spojené se cvičeními, o diagnostice a léčbě nervových onemocnění. Konal je na I. interní klinice prof. Kristiana Hynka (1879-1960), kde působil v letech 1929-1934 jako asistent.

Vladimír Haškovec (1903-1970) se rozhodl kráčet ve stopách svého otce. V roce 1934 se habilitoval z psychiatrie a neuropatologie a od zimního semestru 1934/35 spojoval svoji 
přednášku o terapii duševních chorob s neurologickým praktikem. Konal ji na psychiatrické klinice. V zimním semestru 1936/37 a letním semestru 1937 přednášel na ortopedické klinice prof. Jana Zahradníčka (1882-1958) o neurologické kasuistice z hlediska praxe ortopedické a dětské chirurgie. Neurologicko-chirurgická problematika ho přivedla i ke spolupráci s tehdy docentem ortopedie a dětského lékařství Otakarem Hněvkovským (1901-1980). Ten již v zimním semestru 1937/38 ohlásil přednášku o operativním léčení následků nervových chorob a spolu s V. Haškovcem pak přednášeli od letního semestru 1938 do zavření českých vysokých škol na klinice dětské chirurgie a ortopedie znovu o operativním léčení následků nervových chorob.

Eduard Bena (1899-1976) se habilitoval z neuropatologie v roce 1936. Své docentské přednášky o nových směrech v metodologii neurologie zahájil na neurologické klinice v zimním semestru 1936/37. V dalších semestrech až do zavření českých vysokých škol zaměřoval své přednášky na elektrodiagnostiku a chronometrii. Bena je považován za zakladatele oboru fyziologie práce $\mathrm{v}$ našich zemích.

I v těžké politické situaci, v osudových létech 1938/39, kdy nad našimi zeměmi visela hrozba německého nacismu, dva další docenti ohlásili své neurologické přednášky. Václav Pit'ha ml. (1908-1974) se habilitoval z neurologie v roce 1938 a od zimního semestru 1838/39 ohlašoval přednášku o symptomatologii nervových chorob. Karel Mathon (1905-1971) se stačil habilitovat z neurologie jako poslední před zavřením českých vysokých škol - v červenci roku 1939. Přednášku o diagnostice nervových chorob spojenou s praktickým cvičením hodlal konat na II. Interní klinice prof. Pelnáře. Zda se v onom pohnutém a jen několik týdnů trvajícím školním roce 1939/40 konala, se mi nepodařilo zjistit.

Nemůžeme zde uvádět citace neurologických publikací jednotlivých přednášejících. Pokud byla jejich bibliografie publikována, najde se odkaz na ni v uvedeném Biografickém slovníku pražské lékařské fakulty.

\section{Ladislav Haškovec a založení neurologické kliniky}

Ladislav Haškovec se narodil 18. května $1866 \mathrm{v}$ početné rodině ( 9 dětí) malého obchodníka s látkami v Bechyni. Gymnázium absolvoval v Jindřichově Hradci; po maturitě v roce 1885 se přihlásil na českou lékařskou fakultu, na níž získal 31. ledna 1891 titul MUDr. Jako medik pracoval v letech 1888-1889 v Národním muzeu u prof. Antonína Friče (1832-1913) v kraniologické laboratoři a poté v letech 1890-1891 jako demonstrátor v patologickoanatomickém ústavu prof. J. Hlavy. Nabízené místo asistenta zde nepřijal, toužil po klinické dráze internisty. Proto pracoval jako externista na interní klinice prof. Maixnera. Toto místo nebylo placené, vyhlídky na asistentské místo byly až ve vzdálené budoucnosti, a proto Haškovec přijal od 1. 1. 1892 asistentské místo na psychiatrické klinice u prof. Kuffnera. V zimním semestru roku 1892/93 získal cestovní stipendium, které strávil především v Paříži na slavné neurologické klinice prof. Jeana M. Charcota (1825-1893), zakladatele neurologie jako samostatného lékařského oboru. Navštěvoval tu přednášky i dalších významných představitelů francouzských lékařských věd, kteří tehdy udávali směr jejich vývoje. Tento pařížský pobyt byl rozhodující pro Haškovcovu celoživotní vědeckou orientaci. Podávají o tom svědectví i dvě jeho publikace: Zápisky z Pařiže (Praha 1895, vlast. nák1.) a Profesor Jan Martin Charcot, zakladatel moderní nauky o nemocech nervových 
(Praha, J. Otto 1895). Na psychiatrické klinice setrval až do své habilitace z neuropatologie 21. 8. 1896. Svoji habilitační přednášku Haškovec nazval $O$ významu autointoxikace pro choroby nervstva a od té doby se již věnoval výhradně neurologii jak v oblasti laboratorně-experimentální, tak i klinické. Po habilitaci si Haškovec otevřel soukromou praxi v Perlové ulici č. 9.34

Soustavně začal přednášet od letního semestru roku 1897. Ohlásil hned dvě přednášky: O neurastenii a jejich př́ičinách (1 hodina týdně v posluchárně všeobecné a experimentální patologie, tehdy umístěné v Kateřinské ul.), druhou nazval Casuistikum chorob nervových, praktický návod $k$ vyšetřování nemocných. Také na ni počítal jednu hodinu, ale uvedl, že čas a místo určí později. Nevíme tedy, kdy přesně tuto svou přednášku pronesl poprvé. Víme však, že Haškovec vypisoval své přednášky bez přerušení až do letního semestru roku 1936, kdy ukončil svoji akademickou dráhu. $V$ tomto semestru zahájil své neurologické přednášky jeho syn Vladimír, jak jsme již uvedli výše.

Je nepochybné, že přednášel rád a rád předával posluchačům zejména své bohaté klinické zkušenosti. Již v zimním semestru 1897/98 hodlal věnovat obecně neurologické tematice tři hodiny.

Nemůžeme zde uvádět přesné názvy Haškovcových přednášek. Vždy nabízel souhrnnou přednášku o symptomatologii a diagnostice nervových chorob (většinou tř́hodinovou) a vedle toho hodinovou kasuistiku nervových chorob spojenou s praktickými cvičeními a návody k vyšetřování nemocných. V zimním semestru 1907/8 a letním semestru 1908 vypsal vedle toho přednášku o sociálním významu nervových chorob určenou posluchačům všech fakult.

Najít ovšem vhodnou posluchárnu nebylo pro Haškovce dlouhá léta snadné. Třeba říci, že celá česká lékařská fakulta trpěla od svého konstituování nedostatkem vhodných poslucháren jak pro teoretické, tak pro klinické obory, ale situace L. Haškovce byla v tomto ohledu jedna z nejhorších. Svědčí o tom i poznámky v seznamech přednášek, v nichž Haškovec často uváděl, že místo a čas přednášky budou oznámeny později a po dohodě, což znamenalo, že v době vydání seznamu Haškovec stále ještě nevěděl, kde nalezne pro své přednášky útočiště. V letech 1897-1903 využíval pro svoji hlavní přednášku posluchárnu experimentální fyziologie $\mathrm{v}$ budově teoretických ústavů v Kateřinské ulici a od zimního semestru 1897/98 začal kasuistiku nervových chorob s praktickými návody k vyšetřování nemocných vyučovat na fakultní poliklinice, tehdy umístěné v málo vyhovujících prostorách v tzv. Kaulichově domě na Karlově náměstí. V letním semestru 1900 ohlásil, že bude kasuistiku přednášet na chirurgické klinice, kde doufal - ovšem marně -, že by zde mohl zř́idit specializovanou ambulanci. Chirurgická klinika mu poskytla útočiště ještě v semestru 1900/01 a poté směl v roce 901/02 přednášet hodinu o elektroterapii na II. interní klinice.

Situace s místem konání přednášek a demonstrací se pro Haškovce nezlepšila ani poté, co byl jmenován v roce 1906 mimořádným profesorem (neplaceným, od roku 1916 mimořádným placeným). Naděje na získání lůžek a př́istupu do laboratoří ve všeobecné nemocnici, klinické základně obou pražských lékařských fakult, byla pro něj stále minimální. Marně se ucházel i o primářské místo v chorobinci Na Karlově, kde bylo mnoho osob

34 Vladimír VondRÁČEK, Ladislav Haškovec psychiatr a jeho doba, Československá psychiatrie 62,1966, s. 204-208. Je zde chybná informace, která se poté traduje v dalších publikacích; Haškovec nebyl první habilitovaný docent neurologie $\mathrm{v}$ rakouské monarchii. Tím byl Arnold Pick (1851-1924) habilitovaný na pražské německé fakultě z psychiatrie a neurologie 24. 6. 1878. E. VencovskÝ, Sto let české psychiatrické, s. 63-92. 
s neurologickými diagnózami. Proto Haškovac rád přijal v listopadu roku 1905 primářské místo v nemocnici milosrdných bratří Na Františku. Jeho předchůdcem zde byl výše zmíněný prof. Th. Petřina.

Nemocnice milosrdných bratří, založená Na Františku po bitvě na Bílé Hoře v roce 1620, patřila až do otevření všeobecné nemocnice na Karlově náměstí na přelomu let 1790/91 k největším a nejlepším pražským nemocnicím. Svoji dobrou odbornou pověst si uchovávala po celou dobu své existence. O pacienty se zde starali dobře vyškolení ošetřovatelé a lékařskou péči zajištovali graduovaní civilní lékaři, někdy i s docentskými a profesorskými tituly. ${ }^{35}$

Haškovec si při nástupu do nemocnice u milosrdných vymínil, že v nemocnici bude mít samostatný primariát se zvláštním oddělením pro nervové choroby. Pro toto první specializované oddělení pro nervové choroby u nás si vybral světlé a vzdušné místnosti v 1. poschodí nádvorní budovy (zbořena při jedné z přestaveb). Nejnutnější vybavení tohoto oddělení obstaral Haškovec na vlastní útraty, vedle toho přispěly čtyři firmy. Jeho zř́izení zdůvodnil Haškovec těmito slovy: „Oddělení pro choroby nervové jest u nás novum. Zápasi i jinde s jistými obtižemi. Jsou povahy finanční, osobni, mistni, ale nikoliv věcné... Z tohoto stanoviska vycházeje, považuji štěpeni v rozsáhlém oboru interni medicíny za postulát svědomí, potřeby pedagogické výchovy i potřeby zájmů pacientových. Tím není řečeno, že by se klinikám interní nemoce nervové braly, jako se neberou klinice chirurgické, okulistické, otiatrické, dermatologické a jiným. Nemocnični odlišeni chorob nervových jest prirozenou věci vývoje, který se pozdrží, ale který během doby všude se provede, jako s úspěchem se $v$ některých zemich stalo." 36

Haškovec zde konal své neurologické přednášky od letního semestru 1907 a oddělení vedl jako kliniku. Z vlastních prostředků ho vybavil nutnými učebními pomůckami a ze svého platil také ústavního sluhu, který zastával i funkce opatrovníka, písaře, fotografa a trochu i asistenta. ${ }^{37}$ Činnost úspěšného pracoviště, na jehož půdě vznikla řada cenných publikací, byla zrušena v druhém roce první světové války (1915), kdy se vše podřizovalo válečným potřebám. Ztráta tohoto oddělení byla Haškovcovi alespoň částečně nahrazena tím, že získal pro neurologickou ambulanci možnost využívat prostor laryngologického ústavu v Kaulichově domě na Karlově náměstí. V roce 1916 byl však Haškovec povolán do armády a odvelen do Pardubic, ke své práci na fakultě se navrátil až v roce 1917.

Stále usilovně hledal pro své pracoviště potřebné umístění a po ukončení války a vzniku samostatného státu $\mathrm{v}$ roce 1918 se mu podařilo získat $\mathrm{v}$ Kaulichově domě prostory využívané před tím $\mathrm{k}$ válečným potřebám. Místnosti upravil pro svoji Ambulanci pro choroby nervové, která zde zahájila činnost v letním semestru 1919. Zř́idil zde i laboratoře serologicko-chemickou, histologickou a klinickou. Poprvé získal i řádného placeného asistenta - Jana Šebka (1895-1959). Na sklonku téhož roku (24. 12.) byl Haškovec jmenován

35 Petr SvobodnÝ - Ludmila HLaváčKová, Pražské špitály a nemocnice, Praha 1999, s. 29-34.

36 Ladislav HAšKоvec, Deset let oddělení pro choroby nervové v nemocnici Milosrdných Bratří v Praze, Revue. Neuropsychopathologie, therapie, fysikální medicína, veřejná hygieny, lékařství sociální, dědičnost a eugenika 12, 1915, s. 422.

37 Jan ŠEBeK, Životní ideál profesora Haškovce - česká klinika pro choroby nervové, in: II. Sborník prací na počest Prof. Dr. Ladislava Haškovce k jeho 65. narozeninám. Revue v neurologii a psychiatrii 28/5-7, 1931, s. 113-126, TÝž, Sedmdesátka prof. dr. Ladislava Haškovce, ČLČ 75, 1936, s. 627-630. 
řádným profesorem a tím se stal i examinátorem z neurologie a psychiatrie, ale o získání klinických lůžek se nadále musel starat sám.

Již v březnu roku 1920 na schůzi profesorského sboru se Haškovec zasazoval ,za zřizení kliniky pro choroby nervové“،. Sbor doporučil, aby se návrhem zabývala klinická komise. ${ }^{38}$ O tom, jaké stanovisko tato komise k Haškovcovu požadavku zaujala, se zatím nepodařilo nic zjistit.

V roce 1921 začal Haškovec jednat o to, aby ambulatorium a klinika pro choroby nervové byla umístěna v budově nemocnice pražského obchodnictva, zajímavé novogotické stavbě, která byla otevřena v roce 1862 v Kateřinské ulici s kapacitou cca 40 lůžek (dnes sídlo Ústavu normální a patologické a klinické fyziologie III. LF UK). ${ }^{39}$ Jednání iniciovaná Haškovcem, který byl v té době ústavním lékařem této nemocnice, probíhala mezi lékařskou fakultou, ministerstvem školství a gremiem pražského obchodnictva do počátku roku 1923. Uvažovalo se jak o koupi, tak o pronájmu pro potřeby neurologické kliniky, ale nevyšla ani jedna z variant. ${ }^{40}$ Od jara roku 1923 proto usiloval L. Haškovec o získání místností pro rozšíření svého ambulatoria pro choroby nervové v Kaulichově domě, kde se uprázdnily některé místnosti. Hodlal tam zařídit lůžka, posluchárnu, i místnosti pro asistenta a zř́zence. Nabízel, že úpravy a péči o pacienty by zajistil jím založený Spolek pro zř́zení lidového sanatoria pro péči o nervově choré. Ani tento jeho záměr nevyšel. ${ }^{41}$

Nová naděje na získání klinických lůžek svitla L. Haškovcovi, když se začalo jednat o převzetí chorobince Na Karlově do svazku lékařské fakulty. Bývalý klášter u unikátního osmibokého chrámu P. Marie a sv. Karla Velikého, založený Karlem IV. okolo r. 1379, zbarokizovaný v polovině 17 . století, byl v rámci josefínských reforem rozhodnutím ze srpna roku 1789 přeměněn na chorobinec určený péči o chudé osoby stižené nevyléčitelnými a odpor vzbuzujícími chorobami, mrzáky i osoby, které nemohly pracovat z důvodů choroby či sešlosti věkem. ${ }^{42} \mathrm{~V}$ areálu bývalého kláštera bylo okolo 300 lůžek.

Fakultní komise pro převzetí chorobince Na Karlově do svazku lékařské fakulty ve složení profesoři Ladislav Syllaba (1868-1930, internista, omluven), Ladislav Haškovec, Antonín Heveroch a František Procházka (1864-1934, prof. sociálního lékařství) se sešla 27. 6. 1923. Prof. Procházka připomenul, že mezi obyvateli chorobince je hodně nervově nemocných. L. Haškovec prohlásil, že je ochoten ujmout se lékařské péče v chorobinci, bude-li mu umožněno převést tam svoje nervové ambulatorium s asistentem a laboratoří a dostane dvacet klinických lůžek. ${ }^{43}$ Poté probíhala jednání s Chudinským úřadem hl. města Prahy, do jehož kompetence chorobinec Na Karlově spadal. ${ }^{44}$ Lékařskou péči o pacienty s interními chorobami zajišt'oval tehdy na Karlově mimořádný profesor Rudolf Richard Eiselt (1881-1950).

38 Archiv Univerzity Karlovy, Protokoly profesorského sboru lékařské fakulty (dále jen AUK, Protokoly), 4. 3. 1920 , bod 31.

39 P. SvobodnÝ - L. HlaváčKová, Pražské špitály a nemocnice, s. 86.

40 AUK, fond Lékařská fakulta Univerzity Karlovy (1883-1953) /dále f. LF/, Osobní spis L. Haškovce, kart. 17, přípis gremia praž. obchodnictva ministerstvu školství ze 17. 9. 1921; přípis ministerstva školství děkanátu lékařské fakulty z 27. 10. 1921; prŕípis L. Haškovce profesorskému sboru lékařské fakulty z 30. 1. 1923 a děkanátu fakulty z 1. 10. 1923.

41 Tamtéž, přípis Haškovce ministerstvu školství z 26. 4. 1923.

42 P. SvobodnÝ - L. HlaváčKová, Pražské špitály a nemocnice, s. 51-55.

43 AUK, f. LF, kart. 17, Osobní spis L. Haškovce, zápis komise z 27. 6. 1923.

44 Tamtéž, prŕípis Chudinského úřadu hl. m. Prahy profesorskému sboru fakulty z 12. 11. 1923. 
Nutno říci, že Haškovcovo úsilí o zřízení neurologické kliniky nacházelo velmi malé porozumění u jeho vrstevníka a oborového kolegy, výše zmíněného profesora psychiatrie a neurologie, Antonína Heverocha. Je dochován dopis Heverocha děkanovi lékařské fakulty (byl jím tehdy lékařský chemik Em. Formánek) z 23. 7. 1924, v němž píše, že otázka zřízení neurologické kliniky nebyla projednána v profesorském sboru, na Karlově dle něho nemůže vzniknout klinika, protože ústav má jiné podmínky přijímání nemocných, a stejně tak jako Haškovec by mohl i prof. Eiselt žádat, aby tam byla zř́zena interní klinika. Děkanát pak doporučil Haškovcovi, aby vzal Heverochovy připomínky v úvahu. ${ }^{45}$ Haškovec ovšem v úsilí o založení neurologické kliniky nepolevil.

Na podzim pak probíhala další jednání mezi Haškovcem, ministerstvem školství, děkanátem a pražským chudinským ústavem o vymezení kompetencí, dotacích apod. Dne 4. 9.1924 děkanát sdělil ministerstvu školství, že profesoři Haškovec a Eiselt jsou ochotni od 1. 10. t. r. převzít na Karlově oddělení neuropatologické a interní, Eiselt i péči o choré v chudobinci u sv. Bartoloměje pod Slovany (v místech dnešního ministerstva spravedlnosti). Jednání mezi zmíněnými institucemi se ovšem táhla ještě další měsíce.

Až 8. dubna 1925 sdělil Haškovec ministerstvu školství, že od 1. dubna převzal lékařskou péči v chorobinci Na Karlově a označil ,ziskání tohoto ústavu $k$ účelưm bádacím a vyučovacím za znamenité obohaceni lékařské fakulty“. V př́ípisu také velmi pochvalně (dle mého až překvapivě) popsal ústav jako budovu s mnoha vzdušnými, světlými a účelně upravenými místnostmi pro 300 nemocných s téměř výhradně nejrozmanitějšími nervovými a mozkovými chorobami, což byl velmi cenný demonstrační materiál. Napsal, že je to „sám neurologický ústav, jehož zřizeni pro potřeby fakulty od let již studenstvo a lékařstvo se domáhá a jehož se nízepsaný od počátku své akademické dráhy dožaduje“.46

Haškovec tedy konečně získal velký lůžkový ústav, ale ještě zbývalo dotáhnout do konce úsilí, aby v jeho zdech konečně byla zřízena neurologická klinika.

Dochován je Haškovcův přípis ministerstvu školství z června roku 1925, v němž opět popisuje své pracoviště na Karlově tak, aby mohlo být prohlášeno za kliniku. Z 30 místností vyčlenil devět pro klinické pacienty výlučně s nervovými chorobami, kteří vyhovují jak k výuce, tak k ,bádání“. Pečovalo o ně devět školených ošetřovatelek a dva, bohužel nehonorovaní asistenti, na ženském oddělení Břetislav Studnička (1898-1985), na mužském Ladislav Holeček (1899-1984). Klinika neměla posluchárnu (ale ta se dle Haškovce mohla levně zř́dit), laboratoře a ambulanční místnost. Skromnou laboratoř Haškovec neprodleně zřídil a začal na Karlově přednášet i konat rigorózní zkoušky. Haškovec v tomto přípisu nazýval své pracoviště na Karlově ,klinickým ústavem“. ${ }^{47}$

V listopadu roku 1925 napsalo ministerstvo školství děkanství lékařské fakulty, že poté, co fakulta převzala lékařskou péči o chovance v chorobinci na Karlově, bylo by dobře toto Haškovcovo pracoviště vhodně pojmenovat, a proto ministerstvo očekává návrh profesorského sboru. ${ }^{48}$ Sbor logicky požádal Haškovce, aby se vypracování návrhu ujal sám. Profesorskému sboru jej zaslal Haškovec 1. 3. 1926. Znovu podrobně popisuje celý ústav, který v té době pečoval o 320 nemocných, z nichž 90 \% bylo stiženo neurologickými chorobami. V 1. patře už byla posluchárna pro 50 prrítomných a šest nemocničních pokojů, velkých,

45 Tamtéž, přípis děkanství Haškovcovi z 31. 7. 1924.

46 Tamtéž, prrípis Haškovce ministerstvu školství z 8. 4. 1925.

47 Tamtéž, prúipis z 21. 6. 1925.

48 Tamtéž, príípis z 24. 11. 1925. 
vzdušných, „ř́ádně hygienicky“ vybavených, které byly upraveny na klinické pokoje výlučně pro pacienty s neurologickými chorobami (arteriosklerózy mozkové s následnými poruchami řeči, hemiplegie, př́pady thalmického syndromu, poruch smyslových, paralys agitans, encefalitických syndromů, parkinsonské hemiathetosy, hemichorey, různé druhy třasu, kontraktur, lues mozkové, progresivní paralysy, choroby Littleovy). Haškovec zde také rekapituloval své dlouholeté úsilí o zřízení neurologické kliniky a navrhl, aby jeho pracoviště na Karlově bylo nazváno „Klinika pro choroby nervové“.49

Nutno říci, že prameny dochované v univerzitním archivu nám nedovolují vysvětlit určité nesrovnalosti v chronologii závěrečných jednání o založení této kliniky. Máme k dispozici přípis ministerstva školství děkanátu lékařské fakulty z 12. ledna 1926, který bychom mohli nazvat zakládací listinou této nové kliniky, nebot' se v něm praví, že ministerstvo souhlasí $\mathrm{s}$ návrhem profesorského sboru, aby se ústav pro choroby nervové v městském chorobinci na Karlově nazýval „klinikou pro choroby nervové“ $s$ tím, že ambulatorium pro choroby nervové dosud umístěné v Kaulichově domě bude např́̌ště tvořit součást této kliniky. Ministerstvo vyslovilo i souhlas s tím, aby prof. Haškovec disponoval personálem, inventárem a dotací ambulatoria i na neurologické klinice. Očekávalo také, že dostane návrhy, kde a jak budou umístěny laboratoře histologická, serologická a chemická. Na zadní straně tohoto ministerského přípisu se ovšem dozvíme, že děkanátu lékařské fakulty došel tento přípis až 16. 4. 1926 (! L. H.) a profesorský sbor fakulty to vzal na vědomí na své schůzi 22. 4. 1926. Zápis z této schůze je dochován. ${ }^{50}$ Zde si klademe otázku, na níž neznáme odpověd’: Bylo to zaviněno úřednickou chybou nebo měl někdo - jedinec či instituce - zájem na tom, aby tento důležitý př́ípis putoval $\mathrm{k}$ př́jemci čtvrt roku?

V době mezi oním př́ípisem ministerstva školství z ledna roku 1926 a jeho doručením profesorskému sboru v dubnu 1926 se otázkou neurologické kliniky zabývala fakultní klinická komise logicky tak, jako by tato klinika ještě nebyla ministerstvem schválena (protože o tom nevěděla ani ona, ani profesorský sbor). Doporučila profesorskému sboru 9. 3. 1926, aby tento na své následující schůzi, která bude 11.3. 1926, schválil zmíněný písemný návrh prof. Haškovce z 1. 3. 1926, aby z ústavu pro choroby nervové v městském chorobinci na Karlově „realizována byla klinika pro choroby nervové“. Souhlas profesorského sboru byl jednomyslný a 17. 3. t. r. byl zaslán ministerstvu školství. A za měsíc - uvedeného 16. dubna t. r. - dostalo děkanství lékařské fakulty onen zásadně důležitý lednový přípis ministerstva školství se svolením, aby ústav pro choroby nervové na Karlově, jehož součástí je ambulatorium pro choroby nervové v Kaulichově domě, se nazýval Klinikou pro choroby nervové. ${ }^{51}$

L. Haškovec dostal svoji nelehce vybojovanou kliniku k šedesátým narozeninám, které slavil o měsíc později (18. 5.), ve svém děkanském roce. Stál v jejím čele deset let.

V polovině roku 1926 se začalo jednat mezi pražskou obcí, lékařskou fakultou a ministerstvem školství o koupi chorobince na Karlově v souvislosti s výstavbou velkolepě pojatého městského sociálnězdravotního ústavu v Krči. Ke koupi však nakonec nedošlo. ${ }^{52} \mathrm{Od}$

49 Tamtéž, přípis z 1. 3. 1926.

50 Tamtéž; dále AUK, Protokoly profesorského sboru lékařské fakulty, kart. 5, zápis z 22. 4. 1926, bod 24.

51 AUK, f. LF, kart. 17, Osobní spis L. Haškovce, přípis ministerstva školství děkanství lékařské fakulty z 12.1. 1926.

52 Tamtéž, př́ípis Haškovce ministerstvu školství z 2. 6. 1926; přípis ministerstva školství Radě hl. města Prahy z 30. 7. 1926; prŕípis profesorského sboru ministerstvu školství z 3. 11. 1926. 
roku 1926 vyrůstaly v Krči pavilony tzv. Masarykových domovů a dva pavilóny byly určeny pro nervově choré ležící pacienty, muže i ženy - celkem 400 lůžek. Prof. Haškovcovi byla svěřena péče i o chovance $\mathrm{v}$ tomto novém ústavu, o interní pacienty zde pečoval prof. R. Eiselt. ${ }^{53}$ Počítalo se s tím, že do Krče budou přestěhováni chovanci z Karlova a ten by mohl být využit pro potřeby lékařské fakulty. Masarykovy domovy přijaly první chovance v květnu roku 1929. Haškovcovi se pak podařilo získat na Karlově uvolněné prostory pro znovuzř́zení ambulatoria pro choroby nervové, které zde mělo ambulanci, terapeutické pokoje, histologicko-serologickou a chemickou laboratoř, knihovnu, posluchárnu, pracovnu profesora, pokoje asistentů a pokoj s několika klinickými lůžky, na která byli přiváženi vhodní pacienti z Krče..$^{54}$

V univerzitním archivu se bohužel nedochovala akta z činnosti Haškovcovy kliniky v prvých deseti letech její existence (1926-1936), kdy ji ř́dil. ${ }^{55}$ Ze seznamů přednášek a osob můžeme zjistit, kdo za Haškovcovy éry na jeho klinice pracoval. Jeho první, již několikrát zmíněný asistent Jan Šebek získal asistentské místo u Haškovce ještě jako medik $\mathrm{v}$ červenci 1918 (promoval až $\mathrm{v}$ roce 1920) a v této funkci na klinice pracoval i jako docent (1927) a mimořádný profesor (1933) do roku 1937. Krátce na klinice pobyl Jaromír Markl (1894-1962) - od června 1920 do května 1921, s titulem „náhradního“ asistenta. Také Vlastimil Bartoš (1897-1961) nastoupil ještě jako medik v říjnu 1921 (promoval v lednu 1922). V únoru 1923 přešel jako asistent na Komenského univerzitu do Bratislavy. Václav Zoubek (1897-1933) byl nehonorovaným asistentem kliniky necelý rok (únor 1923 - záŕí 1923). Josef Wiener (1901-1983) nastoupil už rok před promocí od ledna 1923 na kliniku jako pomocná vědecká síla. Asistentské místo zastával od roku 1924 do roku 1926, v červenci roku 1939 odešel do USA, kde se pod jménem Winn uplatnil jako významný neurolog ve vedoucích funkcích v několika newyorských nemocnicích. Břetislav Studnička (1898-1985) byl nehonorovaným asistentem od dubna 1925 do listopadu 1927. Jen několik měsíců - od dubna roku 1924 do prosince téhož roku - byl asistentem kliniky Ladislav Holeček (1899-1984), rovněž nehonorovaný. Druhým habilitovaným pracovníkem kliniky po J. Šebkovi byl Eduard Bena (1899-1976). Nastoupil na kliniku v zimním semestru roku 1925/26 jako pomocná vědecká síla, tři roky před promocí. Nehonorovaným asistentem byl v letech 1929-1945, od roku 1936 s docentským titulem.

V seznamech přednášek je poprvé uvedeno Haškovcovo pracoviště jako klinika v zimním semestru roku 1926/27. Uvádí se zde, že vedle placeného asistenta V. Šebka a neplaceného B. Studničky jsou neobsazena dvě nehonorovaná asistentská místa. Na klinice pracovaly tři pomocné vědecké síly, zř́zenec a myčka. V dubnu roku 1927 přišel na kliniku další nehonorovaný asistent, Fjodor Nikolajevič Dosužkov (1899-1982), rodák z Baku. Na klinice pracoval do roku 1934. První žena - asistentka kliniky - byla Františka Bodláková (1895-1960). Nastoupila na místo pomocné vědecké síly v dubnu roku 1926, dva roky před promocí. Jako asistentka zde působila od ledna 1929 do června 1933. Poté pracovala

53 Petr ZENKL, Masarykovy domovy, sociální ústav hlavního města Prahy, Praha Krč, Zvl. otisk z čas. Čsl. nemocnice 1/5-6, 1935-1936. AUK, f. LF, kart. 17, Osobní spis L. Haškovce, př́ípis Haškovce děkanovi z 14. 10. 1928. Hana Mášová, O stavbě Masarykových domovio, sociálních ústavů Hlavního města Prahy, Dějiny věd a techniky 29/2, 1996, s. 101-116.

54 Jan ŠEBEK, Malé vzpomínky na velikou práci, ČLČ 80, 1941, s. 807-810.

55 AUK, f. LF, kart. 282, Neurologická klinika 1920-1945, ve složce nalezneme jen údaje o platech zaměstnanců, žádosti o zvýšení dotace apod. 
v psychiatrických léčebnách. Karel Uttl (1903-1988) přešel jako asistent na neurologickou kliniku z psychiatrické kliniky v roce 1931 a působil zde v této funkci do března 1937. Poté se uplatnil v terénu jako neurolog a psychiatr. Ella Folkmannová, provdaná Klimková-Deutschová (1906-1981) zahájila svoji neurologickou kariéru na Haškovcově klinice jako nehonorovaná asistentka v letech 1931-1933. V rozmezí 1933-1939 působila ve stejné funkci na neurologicko-psychiatrické klinice na Masarykově univerzitě v Brně. Její úspěšná vědecká dráha byla násilně přerušena v letech 1942-1945, kdy prošla několika koncentračními tábory. Po osvobození naší země v květnu roku 1945 se již 1. 6. vrátila na svoji pražskou kliniku. V roce 1962 se zde habilitovala, a od téhož roku vedla neurologickou kliniku na plzeňské lékařské fakultě, od roku 1967 jako profesorka. Ve stejném roce jako E. Klimková-Deutschová (1931) přišel na kliniku jako další asistent František Stř́zzek (1895-1974). V roce 1934 odešel, aby se věnoval soukromé neurologické praxi. Chorvat Drago Šarič (1899-1955) byl asistentem kliniky v letech 1932-1937, v roce 1937 byl zástupcem přednosty kliniky, poté také on se věnoval soukromé praxi. Josef Apetaur (1898-1955) pracoval na klinice od roku 1929, nejprve jako vědecká síla, v letech 1933-1936 jako asistent, pak přešel na kliniku psychiatrickou, kde se v roce 1948 z psychiatrie habilitoval. Josef Černáček (1909-2006) byl asistentem kliniky v letech 1935-1939, poté odešel na neuropsychiatrickou kliniku Komenského univerzity v Bratislavě, kde se $\mathrm{v}$ roce 1946 habilitoval z neurologie a psychiatrie a v roce 1947 zde získal profesuru. Marie Vinařová (provd. Čmolíková, 1908-1989) pracovala na klinice od roku 1935 jako demonstrátorka a pomocná vědecká síla, v letech 1937-1938 jako asistentka, ale v terénu působila jako praktická lékařka.

V březnu roku 1936 se Haškovec rozhodl, že odejde začátkem školního roku 1936/37 na odpočinek. ${ }^{56}$ Vysokoškolští profesoři tehdy sloužili do sedmdesáti let, měli ještě možnost požádat o prodloužení o jeden „čestný rok“, ale této možnosti Haškovec nevyužil. Po jeho odchodu zůstalo přednostenské místo na jeho klinice určitý čas neobsazeno, prof. Henner ji vedl až od 1. 10. 1937. Haškovec na svoji kliniku ještě nějaký čas docházel, ale sil mu ubývalo. Jeho těžká cukrovka si nakonec vyžádala amputaci dolní končetiny. Od roku 1936 se vzdal i své soukromé praxe. Vědecky a literárně pracoval dále, bohužel se mu nepodařilo dokončit naši první učebnici neurologie, V̌̌eobecnou symptomatologii a diagnostiku chorob nervových, kterou chystal od docentských let. ${ }^{57}$ Haškovec publikoval od studentských let; podrobnou bibliografii sestavil a publikoval jeho žák J. Šebek u př́ležitosti 60 . výročí Haškovcova narození. ${ }^{58}$

Profesor Ladislav Haškovec zemřel v Praze, za okupace, 16. ledna 1944. Cílem naší rozpravy nebylo osvětlit život a dílo zakladatele naší neurologické kliniky, nicméně zde uved’me alespoň hlavní oblasti jeho vědecké a společenské činnosti. Neurologii pojímal velmi široce $\mathrm{v}$ souvislostech $\mathrm{s}$ internou, psychiatrií $\mathrm{i}$ endokrinologií. Velmi ceněné jsou např. jeho práce o štítné žláze a neurohistologii. $Z$ jeho bibliografie vidíme, že se zabýval i antropologií, eugenikou, fyzioterapií, prevencí a duševní hygienou. Měl velké porozumění pro sociální problémy, kterým se věnoval v řadě svých publikací.

56 AUK, f. LF, dodatek, kart. LF UK Prof. sbor 1935-1939, Zasedání profesorského sboru 1935-1936, schůze 26. 3. 1936.

57 Jan ŠEBEK, Za profesorem Haškovcem, ČLČ 83,1944, s. 182.

58 Jan ŠEвek, Prof. dr. Ladislav Haškovec, ČLČ 65, 1926, s. 769-777, a TÝž, Prof. L. Haškovec, Revue v neurologii a psychiatrii 23,1926 , s. 129-140. 
Byl zakladatelem a čestným členem České eugenické společnosti, zakladatelem Společnosti pro potírání chorob pohlavních, čestným členem Spolku pro péči o nervově choré, členem Balneologické a klimatologické společnosti a řady zahraničních vědeckých společností.

Výnosy ze soukromé praxe mu umožnily, že se rozhodl vydávat vlastním nákladem specializovaný odborný časopis, který nazval Revue v neurologii, psychiatrii, fysikální a diaetetické therapii. První číslo vyšlo na počátku roku 1904 a jeho čtenáři se na první stránce dozvěděli, jaké pohnutky vedly Haškovce $\mathrm{k}$ založení nového lékařského časopisu. Připomněl zde, že Časopis lékařů českých a Rozhledy lékařské byly zaměřeny univerzálně. Zdůraznil, že z interních disciplín, velmi důležitých pro praktické lékařství, se v poslední době překotně rozvinula neurologie a psychiatrie, které hluboce zasáhly i do života sociálního, právnického a pedagogického. Proto se rozhodl vydávat tento nový měsíčník, který měl být $\mathrm{v}$ prvé řadě informačním zdrojem pro praktické lékaře. $\mathrm{V}$ následujících letech se název poněkud obměňoval (v roce 1911 to byla Revue v neuropsychopatologii, veřejné hygieně a lékařstvi sociálnim; 1915 Revue. Neuropsychopathologie, theorie, fyzikální medicina, veřejná hygiena, lékařství sociální, dědičnost a eugenika; 1923 Revue. Neuropatologie, psychiatrie, terapie a lékařstvi sociální; 1926 Revue v neurologii a psychiatrii). V zápisech ze schůzí profesorského sboru lékařské fakulty je zřejmé, že Haškovec několikrát žádal o podporu pro vydávání Revue, které se mu vždy dostalo. Revue redigoval do roku 1934.59

Pokusme se zasadit našeho prvního profesora neurologie a zakladatele neurologické kliniky do širších zahraničních souvislostí.

První neurologická klinika byla založena v roce 1882 v Pař́iži zásluhou J. M. Charcota. Přitahovala zájemce o neurologii z celého světa. Po jejím vzoru vznikaly kliniky po celé Evropě, ale v historickolékařské literatuře je jejich dějinám věnováno málo pozornosti; ta se věnuje především dějinám neurologie jako vědy a jejích významných představitelů, většinou $\mathrm{v}$ kontextu dějin psychiatrie. $\mathrm{V}$ jejím rámci je třeba neurologii hledat také $\mathrm{v}$ souhrnných pracích o dějinách lékařství ${ }^{60}$ Určité srovnání nám umožňuje práce zmíněného německého historika medicíny $\mathrm{H}$. H. Eulnera o vývoji lékařských speciálních oborů na univerzitách německé jazykové oblasti, v níž jsou data vzniku samostatných neurologických klinik - i když ne vždy přesně - uvedena. Eulner sledoval 34 lékařských fakult do data vydání své práce (tj. r. 1970). Sedmnáct z nich nemělo samostatnou neurologickou kliniku - byla společná s psychiatrickou. Za pozornost stojí vídeňská fakulta, která měla samostatné neurologické pracoviště již v letech $1846-1868$, znovu pak od roku $1882 .{ }^{61} \mathrm{Na}$ počátku osmdesátých let 19. století vznikly ve Švýcarsku - patrně po vzoru Charcotovy pařížské kliniky - neurologické kliniky v roce 1885 v Zürichu a 1907 v Basileji. V období

59 Česká a slovenská psychiatrie 100, 2004, Supplementum k stému výročí 1904-2004. AUK, f. LF, kart. 282, Neurologická klinika, dotace Ministerstva školství a národní osvěty.

60 Je překvapivé, že napřs. pětidílné dějiny lékařství Richard ToELlner, Illustrierte Geschichte der Medizin, Salzburg 1986 (překlad z francouzštiny), nemají samostatnou kapitolu o dějinách neurologie, ačkoliv ji tam mají daleko menší obory. Obdobně je to v Roy PORTER, Největši dobrodiní lidstva. Historie medicíny od starověku po současnost, Praha 2001. V klasické Garrison's History of Neurology, revised et enlarget with a Bibliography of Classical, Original and Standard Works by Lawrence C. Mc Henry, Springfield-Illinois 1969, nevěnují historii samostatných neurologických lůžek a klinik pozornost.

61 H.-H. Eulner, Die Entwicklung der medizinischen Spezialfächer, dle rejstř́ku; E. Lesky, Die Wiener medizinische Schule, s. 121-125; Jürgen Pfeifer, Hirnforschung in Deutschland 1849-1974, Berlin - Heidelgerg 2004, dle rejstř́ku. 
meziválečném byla v roce 1919 založena neurologická klinika v Hamburku a v roce 1937 ve Würzburgu. O vzniku neurologické kliniky na pražské německé lékařské fakultě je pojednáno v následující kapitole. Další neurologické kliniky byly zakládány až po druhé světové válce. $Z$ uvedeného je zřejmé, že zásluhou profesora L. Haškovce patří pražská lékařská fakulta $\mathrm{k}$ progresivním ústavům, které si byly vědomy nutnosti poskytnout neurologii klinickou základnu, a tím nemalou měrou přispět $\mathrm{k}$ jejímu vědeckému rozvoji.

\section{Neurologie na německé lékařské fakultě od roku 1883 do druhé poloviny 30. let 20. století}

Základní informace o tomto oboru se dozvídali posluchači německé lékařské fakulty - obdobně jako čeští medici - z učebnic. Na rozdíl od české fakulty nevíme, z jakých učebnic studovali, mohly se zde používat učebnice z celé německé jazykové oblasti. Proto jsou pro nás opět důležitým pramenem seznamy přednášek německé lékařské fakulty, $\mathrm{v}$ nichž nalezneme $\mathrm{v}$ chronologickém pořadí, jaká neurologická témata byla posluchačům nabízena zejména $\mathrm{v}$ nepovinných lekcích. Biografické údaje jsou opět $\mathrm{z}$ citovaného biografického slovníku německé lékařské fakulty v Praze. Třeba připomenout, že na rozdíl od učitelů české lékařské fakulty učitelé německé dosti často přecházeli na jiné fakulty německé jazykové oblasti.

$\mathrm{Z}$ teoretiků pokračoval ve svých přednáškách zahájených těsně před rozdělením fakulty (1881/82) zmíněný fyziolog Wilhelm Biedermann (1852-1929). V zimních semestrech školních let 1883/84, 1886/87, 1887/88 a 1888/89 přednášel o fyziologii centrálního nervového sytému, fyziologii míchy a o dýchání a krevním oběhu $\mathrm{v}$ závislosti na nervovém systému. O této problematice uveřejnil řadu studií. V roce 1988 odešel do Jeny.

O funkčních poruchách nervového systému přednášel profesor všeobecné a experimentální patologie Philip Knoll (1841-1900) v jediném (letním) semestru roku 1884. Těžiště jeho odborného zájmu leželo jinde (problematika krevního oběhu a dýchání). Obdobně tomu bylo u jeho oborového kolegy - experimentálního patologa Moritze Löwita (1851-1918). Přednášel o všeobecné patologii centrálního nervového sytému pouze v zimním semestru 1886/87, poté odešel do Innsbrucku.

Ewald H. Hering jun. (1866-1948), rovněž experimentální patolog, ohlásil v zimním semestru 1898/99 přednášku se stejným názvem jako M. Löwit - o všeobecné patologii nervového systému, v zimním semestru následujícího roku 1899/1900 přednášel o poruchách pohybů $\mathrm{v}$ závislosti na nervovém systému. Také on odešel později (1913) do Kolína nad Rýnem. Anatom Hugo Rex (1861-1936) přednášel v zimním semestru 1889/90 o dějinách vývoje centrálního nervového systému smyslových orgánů, ale dále se této problematice nevěnoval. Fyziolog Eugen Steinach (1861-1944) přednášel vždy v letním semestru 1891, 1892, 1893 o fyziologii nervového systému, v letním semestru 1894 nazval svou přednášku fyziologie mozkových nervů. Publikoval několik studií o těchto otázkách. $\mathrm{V}$ roce 1912 odešel do Vídně.

Systematicky a dlouhodobě se zabýval neurologií experimentální patolog Hugo Wiener (1868-1930), trvale působící na pražské lékařské fakultě, jak ve své činnosti vědecké tak i pedagogické. Od letního semestru 1899 až do své smrti každoročně vypisoval dvouhodinovou přednášku o patologii nervových chorob. Také histolog Alfred Kohn (1867-1959) 
ohlašoval svoji přednášku o histologii smyslových orgánů či histologii nervového systému řadu let, od letního semestru roku 1900 až do letního semestru 1911, a publikoval řadu prací s touto tematikou. V letním semestru 1927 se objevilo v neurologických přednáškách poprvé ženské jméno. Hedwiga Langeckerová (1894-1989) se habilitovala v roce 1926 z experimentální farmakologie a v letním semestru 1927 nalézáme její jméno u přednášky o experimentální farmakologii vegetativního nervového systému a jejím působení na lékovou terapii. Dále už se touto problematikou nezabývala. Patolog Kornell Terplan (nar. 1894) ohlásil jen jednu přednášku o patologii centrálního nervového systému v zimním semestru 1927/28, v roce 1930 už působil na lékařské fakultě v Buffalu. Fyziolog Gustav Schubert (1897-1976) nabízel ve fyziologickém ústavu vybrané kapitoly o fyziologii smyslů od letního semestru 1932 až do roku 1939. Histolog Maxmilian Watzka (1905-1981) přednášel v letech 1935/36 o histologii nervového systému a smyslových orgánů. Další žena, Maria Schmidtová, roz. Mittelbachová (nar. 1900) se habilitovala v r. 1936 z patologické anatomie a od zimního semestru 1937/38 přednášela o patologii a histologii centrálního nervového systému.

Vedle třinácti teoretiků ohlašovalo ve sledovaném období přednášky neurologického obsahu dvacet dva kliniků, což svědčí o vzrůstajícím zájmu o tento obor. Tři z nich - internisté - pokračovali v přednáškách, které zahájili na nerozdělené fakultě. Theodor Petrina (Petřina) dále přednášel o lokalizaci nervových onemocnění a elektroterapii nervových chorob až do roku 1901, poté vypisoval přednášky o diagnostice interních chorob se zaměřením na auskultaci a perkusi. Otto Kahler pokračoval na německé lékařské fakultě v přednáškách o chorobách míchy až do svého odchodu na vídeňskou fakultu v roce 1889. Alfred Přibram vypsal jedinou přednášku o chorobách míchy v letním semestru 1896. Psychiatrovi a neurologovi Arnoldu Pickovi se budeme věnovat v závěru této kapitoly.

$\mathrm{V}$ chronologickém pořádku vypisovali přednášky s neurologickou problematikou tito další klinici: internista Jacob Singer (1853-1926) zahájil své docentské přednášky o chorobách nervového systému na 1 . interně v zimním semestru 1886/87, s obměněným názvem je ohlašoval do zimního semestru 1893/94 (od roku 1889 jako profesor vnitřního lékařství). Uveřejnil několik časopiseckých studií s neurologickou problematikou.

Rudolf Jaksch (1855-1947), jedna z nejvýraznějších osobností nejen německé fakulty, ale i celé univerzity a př́slušníků německé národnosti u nás, mezinárodně uznávaný internista, ohlásil hodinovou přednášku dvakrát v týdnu v letním semestru 1890, již jako profesor vnitřního lékařství a přednosta II. interní kliniky. Nazval ji patologie a terapie nervových chorob a konal ji - s podivem - nikoliv na své klinice, ale v posluchárně ústavu lékařské chemie, ačkoliv měl na své klinice specializovanou ambulanci pro choroby nervové. ${ }^{62}$ Rudolf Limbeck (1861-1900) byl habilitován z vnitřního lékařství v roce 1890 a v letních semestrech 1891 a 1892 přednášel na 1. interní klinice o neuropatologii. Následujícího roku odešel do Vídně. Neurologií se blíže nezabýval.

Internista Egmont Münzer (1865-1924) se naopak zabýval neurologií soustavně jak ve své vědecké tak i pedagogické činnosti. Přednášky nazývané patologie a terapie nervových chorob s klinickými demonstracemi na II. Interní klinice konal soustavně od zimního semestru 1893/94 do zimního semestru 1905/06. V roce 1907 získal profesorský titul 
a poté přednášel o různých tématech z vnitřního lékařství. Úzce spolupracoval se zmíněným J. Singerem.

Také internista Gottfried Pick (1867-1926) vypisoval přednášky o stavbě centrálního nervového systému a diagnostice nervových chorob po řadu let - od zimního semestru 1897 do zimního semestru 1909/10. Publikoval tři neurologické statě.

Alexander Marguliés (1870-1921) se v roce 1902 habilitoval z psychiatrie, ale téma jeho docentských přednášek od zimního semestru 1902/03 bylo neurologické - propedeutika k patologii centrálního nervového systému. Od zimního semestru 1905/06 ohlašoval přednášky o duševních chorobách a v roce 1909 získal mimořádnou profesuru z tohoto oboru. K neurologickým přednáškám se vrátil v zimním semestru 1910/11 a konal je v podstatě až do své smrti. Mnoho z této problematiky nepublikoval, ale zasloužil se mj. o založení neurologické stanice pro vojáky a spolku pro péči o epileptiky.

Také další významný psychiatr, profesor Oskar Fischer (1876-1942), habilitovaný z psychiatrie $\mathrm{v}$ roce 1907, věnoval své první přednášky od letního semestru 1908 na psychiatrické klinice neurologickým tématům - normální a patologické histologii mozku, diagnostice nervových a duševních chorob apod. V těchto přednáškách pokračoval i v období meziválečném. V letním semestru 1938 ohlásil svoji poslední přednášku na téma Posudková činnost neurologa. Zahynul v koncentračním táboře v Terezíně. Dnes jsou ceněny zejména jeho studie o př́padech stařecké demence na základě paralelních výzkumů s Aloisem Alzheimerem (1964-1915). ${ }^{63}$

Ernst Emil Sträussler (1872-1959) se habilitoval v roce 1906 z psychiatrie a vstoupil do vojenské služby. V roce 1914 byl jmenován profesorem psychiatrie, ale v roce 1919 př̌šel na vídeňskou fakultu. Za války ohlásil v letním semestru 1917 jedinou neurologickou přednášku o válečných nervových onemocněních. Publikoval velmi málo.

Zcela mimořádnou osobností v dějinách psychiatrie a zejména neurologie nejen $\mathrm{v}$ našich zemích je světově proslulý Arnold Pick (1851-1924). Rodák z Velkého Meziř́čí absolvoval lékařskou fakultu ve Vídni (1875). Již za studií pracoval jako asistent na tamní neurologicko-psychiatrické klinice (1872-1874). V letech 1877-1880 byl sekundářem ústavu choromyslných v Praze, poté do roku 1886 ředitelem zemského ústavu choromyslných v Dobřanech. V roce 1878 se habilitoval z psychiatrie a neurologie na pražské lékařské fakultě. Jeho jméno je spojeno s řadou uznávaných objevů a priorit (např. Pickova nemoc - atrofie mozková, Pickův svazek - v medulla oblongata). Jeho publikační činnost byla úctyhodná, uveřejnil okolo tři set prací, z toho přibližně polovina se zabývá neurologickou problematikou. Pick publikoval převážně v německých periodikách, ale devět jeho studií vyšlo v časopisech amerických, sedm ve francouzských, pět v anglických a jeden ve Švýcarsku. ${ }^{64}$

O založení psychiatrických klinik na pražských lékařských fakultách se začalo vážně jednat až v souvislosti s rozdělením univerzity na českou a německou $-\mathrm{v}$ roce 1883 . Jednání byla dlouhá a složitá, nejproblematičtější byla otázka umístění klinik v ústavu choromyslných v objektu tzv. nového domu v Kateřinské ulici. Kliniky zde dostaly svá lůžka

63 Michal V. ŠImƯNEK - Antonín KostLÁn (edd.), Disappeared science, Červený Kostelec - Praha 2013, s. 52-57.

64 Vladimír VondráčeK, Německá psychiatrická klinika v letech 1882-1945, Čs. psychiatrie 62, 1966, s. 124-130; TÝž, Lékar dále vzpominá, s. 187-189; Ludmila HLAváčKová, K otázce vztahu české a némecké psychiatrické kliniky pražských lékařských fakult do roku 1918, Česká a slovenská psychiatrie 101, březen 2005, s. 108-110; TÁž, Česká a německá psychiatrická klinika pražské lékařské fakulty, s. 133-162; TÁž, Arnold Pick-přednosta Německé psychiatrické kliniky v Praze, ČLČ 146, 2007, s. 411-413. 
v ř́ijnu 1886. V souvislosti s tím byl Pick v červnu 1886 jmenován řádným profesorem psychiatrie a přednostou německé kliniky. V této funkci setrval až do odchodu na odpočinek v roce 1921. Pick věnoval velké úsilí tomu, aby vybavil kliniku nejen $\mathrm{k}$ výuce mediků, ale i k vědecko-výzkumné práci zejména $\mathrm{v}$ oblasti histologického výzkumu nervového systému. Pick ale neuspěl v úsilí o vybudování speciálních neurologických lůžek a ambulance na své klinice. Jednání o alespoň třiceti klinických neurologických lůžkách v roce 1909 nedopadla dobře, stejně jako jednání o zrř́zení specializovaného ambulatoria. Př́íčinou neúspěchu byl zamítavý postoj přednostů obou interních klinik - R. Jaksche a A. Přibrama. Připomeňme, že tito sice na svých klinikách umožňovali specializované přednášky z neurologie, sami se tomuto oboru také věnovali, ale v iniciativě kolegy psychiatra Picka zréejmě spatřovali určité nebezpečí konkurence. Pick přednášel soustavně o neurologii od zimního semestru 1889 až do svého odchodu na odpočinek v roce 1921 (o lokalizaci nervových chorob, chorobách míchy, anatomii nervového systému, někdy jen obecný název klinika nervových chorob). Ačkoliv oficiálně nedosáhl toho, aby své pracoviště mohl nazývat nejen psychiatrickou, ale i neurologickou klinikou, nalezneme v seznamu přednášek letního semestru 1915 název jeho přednášky „Nervenklinik“ a místo konání také „Nervenklinik“ v ústavu choromyslných. Takže Pick si zřejmě na své klinice klinická neurologická lůžka vyčlenil. $\mathrm{O}$ tom, kdy byla německá neurologická klinika zř́zena oficiálně, bude pojednáno ve stati P. Svobodného.

V období meziválečném pozorujeme nárůst přednášek s neurologickou problematikou ohlašovaných kliniky - habilitovanými z psychiatrie a neurologie.

Otto Sittig (1886 - po říjnu 1944 zahynul v Osvětimi) se habilitoval z neurologie v roce 1921 a neprodleně zahájil přednášky z tohoto oboru, které konal nepřetržitě až do tragického roku 1938/39, kdy byla násilně přerušena jeho akademická dráha z rasových důvodů. Své přednášky zaměřoval jak na všeobecné, tak i specializované otázky neurologie (všeobecná neurologie, neurologická diagnostika, elektrodiagnostika, patologická histologie nervového systému aj. $)^{65}$

Otto Pötzl (1877-1962), profesor psychiatrie a neurologie, v roce 1922 nástupce A. Picka ve vedení psychiatrické kliniky, pracoval v letech 1905-1921 na vídeňské klinice nobeláta Julia Wagner von Jauregga (1857-1940). Na pražské klinice přednášel od letního semestru 1922 až do svého návratu na vídeňskou kliniku v roce 1928. Také on konal neurologické přednášky jak obecného zaměření (klinika nervových chorob), tak specializované (např. patologie velkého mozku) a o těchto tématech publikoval. Podle prof. Vondráčka byl blíže neurologii než psychiatrii. ${ }^{66}$ Profesor psychiatrie a neurologie Max Löwy (1875-1948) zaměřoval své přednášky konané od zimního semestru 1923/24, psychologicky, zvláštní pozornost věnoval neurózám. Také on musel v roce 1939 z rasových důvodů rezignovat, terezínské věznění přežil. Podobný byl i osud docenta psychiatrie a neurologie Bruno Fischera (1888-1973) - a jak je uvedeno níže, i řady dalších. Od své habilitace v roce 1925 ohlašoval dvouhodinové neurologické praktikum až do nucené rezignace v roce 1939. I on přežil terezínský koncentrační tábor. Docent psychiatrie a neurologie Georg Hermann (nar. 1891) se habilitoval v roce 1926 a přednášel soustavně až do roku 1939. Své přednášky zaměřoval např. na vyšetřovací metody v neurologii, technické zásahy v neurologii apod.,

65 M. V. S̆IMU゚NEK - A. KostLÁn (edd.), Disappeared science, s. 181-185.

66 V. VONDRÁČEK, Lékař dále vzpomíná, s. 189. 
ale také na lékařskou psychologii. Erwin Hirsch (1888 - po 19. 10. 1944 zahynul v Osvětimi) ${ }^{67}$ se habilitoval z psychiatrie a neurologie v roce 1928 . V roce 1928/29 ohlásil přednášku o onemocnění vegetativního nervového systému, poté do roku 1936/37 přednášel o psychiatrických tématech. Docent psychiatrie a neurologie Franz Theodor Münzer (1895 - po 23. 10. 1944 zahynul v Osvětimi) ${ }^{68}$ habilitovaný v roce 1928 přednášel od letního semestru 1929 až do nucené rezignace v roce 1939. Tématem jeho přednášek byly jak teoretické, tak klinické otázky neurologie (anatomickofyziologické základy neurologie, struktura a funkce nervového systému, diferenciální diagnostika nervových chorob, nejdůležitější nervové a duševní choroby, psychiatrickoneurologické praktikum apod.)

Profesor psychiatrie a neurologie Eduard Gamper (1887-1938) se ujal vedení pražské psychiatrické kliniky v roce 1930. Byl zcela šokován jejím zcela nevyhovujícím umístěním i vybavením, dochoval se jeho popis tohoto tristního stavu. ${ }^{69}$ Gamper byl nesporně významnou osobností, respektovanou kolegy obou pražských fakult. ${ }^{70}$ Splňoval všechny tři základní požadavky na vysokoškolského učitele; byl výborný - náročný - ale oblíbený pedagog, uznávaný vědec i obětavý „správce“ svého pracoviště, i když v této funkci nebyl př́liš úspěšný, nikoliv však svou vinou. Gamper byl převážně neurologicky zaměřený, přednášky z tohoto oboru zahájil v letním semestru 1931. Nazýval je obvykle patologie nervových chorob. Vedle toho vypisoval neurologickopsychiatrické praktikum. Kliniku rrídil osm let, v dubnu roku 1938 tragicky zahynul prri automobilovém neštěstí v bavorských Alpách. S jeho jménem je spojen např. úspěšný výzkum v oblasti anatomie a funkcí mozkového kmene. Velmi usiloval o zřízení neurologické kliniky. V roce 1933 se mu podařilo získat neurologická lůžka v tzv. jubilejním pavilónu ve všeobecné nemocnici; bylo to po smrti experimentálního patologa Artura Biedla (1869-1933), který zde měl malou propedeutickou kliniku. ${ }^{71}$

Docent psychiatrie a neurologie Robert Klein (nar. 1895) ohlašoval neurologické přednášky od zimního semestru 1932/33 do roku 1939. Věnoval se v nich patologii mozku, oku a uchu v nervovém systému a demenci. Ve stejném semestru ohlásil neurologické přednášky také Adalbert Kral (1903-1988). Přednášel do roku 1939 o patofyziologii a klinice onemocnění mozkového kmene a humorálně patologických syndromech v psychiatrii a neurologii.

Srovnáme-li postavení neurologie na české a německé lékařské fakultě ve světle specializovaných přednášek, vidíme, že zájem o tento nově se konstituující obor byl na obou fakultách při přibližně stejném počtu učitelů na jednotlivých oborech téměř stejný. Od roku

67 M. V. ŠIMƯNeK - A. Kostlán (edd.), Disappeared science, s. 86-87.

68 M. V. ŠIMŮNeK - A. Kostlán (edd.), Disappeared science, s. 154-157.

69 Walter Koerting, Die Deutsche Universität in Prag. Die letzten Hundert Jahre ihrer medizinischen Fakultät, Bonn 1968, s. 75-83. Kolega Mgr. Michal Šimůnek, Ph.D. mě laskavě upozornil na společný přípis prof. Gampera a prof. Z. Myslivečka, přednosty české psychiatrické kliniky, Zemskému výboru z 23. 3. 1931 a př́pis prof. Gampera ministerstvu školství z 23. 3. 1937, v nichž je líčen tristní stav obou klinik, viz Národní archiv Praha, fond Ministerstvo školství a kultury, kart. 1028.

70 Velmi pěkně vylíčil jeho osobu V. VONDRÁČEK, Lékař dále vzpomíná, s. 191-193

71 Ludmila HlavÁČKovÁ, Z historie „jubilejního pavilónu“ v pražské všeobecné nemocnici, ČLČ 147, 2008, s. 580-583; V. VondráčEK, Lékař dále vzpomíná, s. 192; Kurt AlBrecht, Prof. Dr. Eduard Gamper, Bericht der Deutschen Universität in Prag über das Studienjahr 1937/38, s. 78-79. 
1883 do 30. let 20. století ohlašovalo na české fakultě neurologické přednášky 11 teoretiků a 23 kliniků; na německé to bylo 13 teoretiků 22 kliniků.

Na obou fakultách se věnovala tomuto oboru řada významných osobností, ovšem do jeho světové historie vstoupili ti, kteří publikovali ve světových jazycích - tedy především Němci. Po rozdělení pražské univerzity a její lékařské fakulty na českou a německou v letech 1882/83 považovali její čeští učitelé za svoji vlasteneckou povinnost publikovat především česky. Tím ovšem ztráceli možnost proniknout svými pracemi na zahraniční fórum. Ocitujme zde velmi výstižný, lapidární výrok prof. Josefa Charváta (1897-1984): „Bohemica non leguntur, si leguntur non citantur."72

Snažila jsem se zjistit, jaké byly odborné styky českých a německých neurologů. Vycházela jsem z úvahy prof. V. Vondráčka o těchto stycích mezi psychiatry: „Nutno si položit otázku, jaký význam měla německá psychiatrická klinika pro vývoj české psychiatrie. Nutno bohužel odpovědět, že téměř stejný, jako kterákoliv jiná klinika cizojazyčná v kterémkoliv jiném státě... Styk vědecký byl nepatrný. "73 Ovšem ve svých vzpomínkách prof. Vondráček na několika místech o těchto stycích hovoří: „Na Pötzlovy přednášky si rádi zaskočili z I. do II. patra Janota a Špringrová. " (prof. Otakar Janota ml. 1898-1969, asistentka Marie Špringrová 1900-1935). Patrně i on sám někdy poslouchal Gampera, protože o něm napsal, že byl nadaný řečník a jeho přednášky byly výborné. Na jiném místě pak popisuje, jak s prof. Gamperem a dalšími kolegy společně večeřeli a velmi prŕíjemně se bavili. ${ }^{74} \mathrm{~V}$ ČLČ také vyšel nekrolog o E. Gamperovi z pera O. Janoty, v němž čteme mj.: „Přilnul záhy k Praze a též s českými neurology a psychiatry měl nejlepši styky. Byl dobře informován o naši práci a se zájmem sledoval, kde co bylo dobrého. Posledni dobou se zabýval myšlenkou svést české i německé neurology a psychiatry ve společných schĩzích vědeckých. "75 Nejen Gamperovo předčasné úmrtí, ale především dramatické politické události, které zanedlouho poté následovaly, realizaci této dobré myšlenky zcela zmařily.

\section{LUDMILA HLAVÁČKOVÁ}

\section{Die Anfänge der Neurologie an den Prager medizinischen Fakultäten und die Gründung neurologischer Kliniken}

\section{ZUSAMMENFASSUNG}

Verfasserin verfolgt die Entwicklung der Neurologie an den Prager medizinischen Fakultäten von den ältesten Zeiten an bis in die 1930er Jahre. Eine wichtige Quelle sind ihr hierbei die Vorlesungsverzeichnisse. Ihnen lässt sich entnehmen, wie die einzelnen Fächer im Rahmen der Pflichtvorlesungen präsentiert wurden und wie man seit den 1840er Jahren mit Spezialvorlesungen begann, die zunächst fakultativ waren, ehe sie dann später im Rahmen der veränderten Anforderungen an den Erwerb des Doktortitels zu Pflichtveranstaltungen wurden. Besondere Aufmerksamkeit ist den Bemühungen des Professors für Neurologie Ladislav Haškovec (1866-1944) gewidmet, der für neurologisch Erkrankte, die bis dahin entweder in internistischen oder in psychiatrischen Kliniken behandelt

72 Ludmila HlavÁČKovÁ, Čeština v medicině a na pražské lékařské fakultě (1784-1919), Práce z dějin vědy, 11, 2003, s. 327-344.

73 V. VONDRÁČEK, Německá psychiatrická klinika, s. 130. Téměř stejnými slovy o tom hovoří ve svých vzpomínkách V. VONDRÁČEK, Lékă dále vzpomíná, s. 149.

74 V. VONDRÁČEK, Lékař dále vzpomíná, s. 191-193.

75 Otakar Janota, Prof. dr. Ed. Gamper, ČLČ 77, 1938, s. 562-563. 
wurden, Krankenhausbetten zu bekommen versuchte. Ziel seiner Bemühungen war die Einrichtung einer neurologischen Klinik. Die medizinische Fakultät, die an einem großen Mangel an Krankenhausbetten litt, hatte für Haškovec' Bemühungen kein Verständnis. Eine erste spezialisierte neurologische Bettenstation gliederten die Barmherzigen Brüder aus ihrem Krankenhaus in Prag Na Františku für Haškovec aus, der dort 1905 als Chefarzt sein Amt antrat. Die Ausstattung derselben besorgte er aus eigenen Mitteln. Bis zum Kriegsjahr 1915 hielt Haškovec hier klinischen Unterricht ab, ehe das Krankenhaus den kriegsbedingten Bedürfnissen untergeordnet wurde. Doch auch nach Entstehung der tschechoslowakischen Republik 1918 war es für Prof. Haškovec nicht leicht, für sein Fach eine reguläre Klinik zu finden. Im April 1925 übernahm Haškovec die ärztliche Betreuung in der Anstalt für Alte und Kranke in Prag Na Karlově, in der es stets viele Patienten mit neurologischen Erkrankungen gab (bis zu 90\%) und wo er ein Institut für Nervenkrankheiten einrichtete. Am 12. Januar 1926 erging die Zustimmung des Ministeriums für Schulwesen, dieses Institut in Klinik für Nervenkrankheiten umzubenennen. An der Spitze dieser Klinik stand Prof. Haškovec zehn Jahre lang, bis zu seiner Pensionierung 1936. Nach der Teilung der medizinischen Fakultät in eine tschechische und eine deutsche mit Beginn des Studienjahres 1883/84 verlief die Geschichte der Neurologie an der deutschen Fakultät in engerer Verbindung mit der Geschichte der Psychiatrie.

Deutsche Übersetzung Wolf B. Oerter

doc. PhDr. Ludmila Hlaváčková, CSc.

Ústav dějin lékařství a cizich jazyků 1. LF UK, Praha

ludmila.hlavackova@lf1.cuni.cz 